\title{
Redox control in the pathophysiology of influenza virus infection
}

\author{
Ker-Kong Chen ${ }^{1,2}$, Moeko Minakuchi ${ }^{3}$, Kenly Wuputra ${ }^{4,5}$, Chia-Chen Ku ${ }^{4,5}$, Jia-Bin Pan ${ }^{4,5}$, Kung-Kai Kuo ${ }^{6}$, \\ Ying-Chu Lin', Shigeo Saito ${ }^{3,7}$, Chang-Shen Lin ${ }^{4,8^{*}}$ and Kazunari K. Yokoyama ${ }^{3,4,5,9^{*}}$ (i)
}

\begin{abstract}
Triggered in response to external and internal ligands in cells and animals, redox homeostasis is transmitted via signal molecules involved in defense redox mechanisms through networks of cell proliferation, differentiation, intracellular detoxification, bacterial infection, and immune reactions. Cellular oxidation is not necessarily harmful per se, but its effects depend on the balance between the peroxidation and antioxidation cascades, which can vary according to the stimulus and serve to maintain oxygen homeostasis. The reactive oxygen species (ROS) that are generated during influenza virus (IV) infection have critical effects on both the virus and host cells. In this review, we outline the link between viral infection and redox control using IV infection as an example. We discuss the current state of knowledge on the molecular relationship between cellular oxidation mediated by ROS accumulation and the diversity of IV infection. We also summarize the potential anti-IV agents available currently that act by targeting redox biology/pathophysiology.
\end{abstract}

Keywords: Antioxidation, Aryl hydrocarbon receptor, Cellular oxidation, Nuclear factor E2-related factor 2, Reactive oxygen species

\section{Background}

Influenza viruses (IVs) have been involved in pandemics and seasonal epidemics and are serious threats to humans [1-4]. IV pandemics have been noted in the past; for example, the Spanish flu caused by the H1N1 IV in 1918, the Asian flu caused by the H2N2 IV in 1957, the Hong Kong flu caused by the H3N2 IV in 1968, the bird flu caused by the H5N1 and H7N9 IVs in 2003 and 2013, respectively, and the swine flu caused by the H1N1 IV in 2009. Vaccination is currently the key strategy against IV infection, although this strategy is limited by the ability to produce effective vaccines that precisely target new and emerging IV strains.

\footnotetext{
* Correspondence: changshenlin@gmail.com; kazu@kmu.edu.tw

${ }^{4}$ Graduate Institute of Medicine, Kaohsiung Medical University, 100

Shih-Chuan 1st Rd., San-Ming District, Kaohsiung 80807, Taiwan

${ }^{3}$ Waseda Research Institute for Science and Engineering, Waseca University, Shinjuku, Tokyo 162-8480, Japan

Full list of author information is available at the end of the article
}

Three drugs (zanamivir, oseltamivir, and peramivir) are structurally related and inhibit neuraminidases on the cell surface membranes of both influenza A and B viruses and are approved by the US Food and Drug Administration [5]. Both amantadine and rimantadine can target the IV M2 protein, to inhibit the proton channel [6,7]. Baloxavir marboxil is a selective drug that inhibits the IV cap-dependent endonuclease, thus preventing IV proliferation by inhibiting the mRNA initiation reaction [8]. However, resistance to anti-IV drugs is a major problem associated with these wellknown therapeutics' agents; moreover, the safety of some of these agents in pregnant women and fetuses is not well defined [9].

Reactive oxygen species (ROS) are often produced during IV infection [10], thus promoting apoptosis, lung injury (LI), and inflammation/allergy [10-13]. These studies indicate the crucial roles of ROS in IV infection, which may have implications for therapy. In this review,

(C) The Author(s). 2020 Open Access This article is licensed under a Creative Commons Attribution 4.0 International License, which permits use, sharing, adaptation, distribution and reproduction in any medium or format, as long as you give appropriate credit to the original author(s) and the source, provide a link to the Creative Commons licence, and indicate if changes were made. The images or other third party material in this article are included in the article's Creative Commons licence, unless indicated otherwise in a credit line to the material. If material is not included in the article's Creative Commons licence and your intended use is not permitted by statutory regulation or exceeds the permitted use, you will need to obtain permission directly from the copyright holder. To view a copy of this licence, visit http://creativecommons.org/licenses/by/4.0/ The Creative Commons Public Domain Dedication waiver (http://creativecommons.org/publicdomain/zero/1.0/) applies to the data made available in this article, unless otherwise stated in a credit line to the data. 
we summarize ROS generation and redox control of the host cells upon IV infection and discuss how ROS can affect IV replication. We also describe the potential therapeutics against IV infection that targets ROS prevention and antioxidation in host cells. In addition, therapies aimed at inhibiting ROS-mediated cell damage are critical for future use. Thus, here we show the advantages and disadvantages of these anti-influenza drugs from new perspectives.

\section{Main text}

\section{ROS generation and antioxidation system in cells}

Mitochondria are the target organelle of oxidation-reduction reactions [14-16]. Mitochondria play major roles in the production of both adenosine triphosphate and ROS during oxidative phosphorylation [15]. The hydrogen peroxide $\left(\mathrm{H}_{2} \mathrm{O}_{2}\right)$, hydroxyl radicals $\left({ }^{\bullet} \mathrm{OH}\right)$, and superoxide anions $\left(\mathrm{O}_{2}^{-}\right)$that are generated mainly during oxidation are classified as ROS [14, 16]. Reactive nitrogen species (RNS) are ROS that contain nitrogen. Based on their chemical properties, ROS/RNS have been divided into two groups: free radicals and non-free radicals. Free radicals are ROS that contain one unpaired reactive electron in the outer orbit and include oneelectron oxidants, such as nitric oxide (NO), carbonate radical anion, nitrogen dioxide, alkoxyl/alkyl peroxyl, ${ }^{\circ} \mathrm{OH}$, and $\mathrm{O}_{2}{ }^{-}$. The non-free radicals do not contain unpaired electrons and include two-electron oxidants, such as peroxynitrite, peroxynitrous acid, hypochlorous acid, singlet oxygen, and $\mathrm{H}_{2} \mathrm{O}_{2}$. Free radicals are unstable and more reactive than non-free radicals. ROS/ NRS target molecules that contain protein residues such as Cys, Met, Tyr, and Trp, and iron-sulfur (Fe-S) bonds. The targeting of ROS to macromolecules such as DNA, RNA, proteins, and lipids leads to various biochemical and pathological alterations [16].

Intracellular ROS are produced mainly by enzymes, such as those in the mitochondrial nicotine adenine dinucleotide phosphate (NADPH) oxidase (NOX)/dual oxidase (DUOX) family [17], xanthine oxidase (XO) [18], cytochrome p450 (CYP) [19], polyamine and amine oxidases (or polyamine-catabolizing enzymes) [20], and lipid-catabolizing enzymes [21]. The mechanisms underlying the production of $\mathrm{O}_{2}^{-}$and the single-electron reduction of 8-nitroguanosine to the respective anion radical via $\mathrm{NADPH}-$ cytochrome $\mathrm{P} 450$ reductase (POR) have been reported [12]. 8-Nitroguanosine is often produced in inflamed or infected tissues [12], and its derivative, 8-nitroguanosine $3^{\prime}, 5^{\prime}$-cyclic monophosphate (8-nitro-cGMP), is also a functional molecule. The metabolic pathways of 8-nitro-cGMP are produced by the inducible nitric oxide synthase (iNOS) enzymes, which react with $\mathrm{SH}$-proteins via S-guanylation, to form 8-SH-cGMP by reacting with endogenous hydrogen sulfide/sulfanyl radical $\mathrm{H}_{2} \mathrm{~S} / \mathrm{HS}^{\bullet}$ [22]. Any of the iNOS enzymes, or even $\mathrm{XO}$, can subsequently transfer electrons to molecular oxygen [23].

The redox homeostasis is maintained in normal cells by the antioxidation reactions, which include the antioxidant systems of several enzymes, such as superoxide dismutases (SODs), catalases (CATs), peroxiredoxins (Prdxs), glutathione peroxidase (GPx), and glutaredoxins (GRs), and a nonenzymatic system, which consists of anserine, carnosine, carotenoids, flavonoids, glutathione (GSH), homocarnosine, melatonin, and vitamins $C$, and $E[24,25]$. The decrease in $\mathrm{GSH}$ /glutathione disulfide (GSSG), which is a cellular antioxidant index, is caused by the reduction in the level of GSH, which acts as a redox buffer within cells [25]. GSH is capable to protect the damages to intracellular components caused by ROS such as free radicals, peroxides, lipid peroxides, and heavy metals. It also plays a critical role in suppressing oxidative stress in several RNA viruses, including IVs [26].

A comparison of the kinetic data of $\mathrm{H}_{2} \mathrm{O}_{2}$ metabolism between thiol targets and GSH has been performed in mammalian cells. The decomposition of $\mathrm{H}_{2} \mathrm{O}_{2}$ by $\mathrm{GSH}$ is dependent on the concentration of $\mathrm{H}_{2} \mathrm{O}_{2}$, and GSH has a lower affinity for $\mathrm{H}_{2} \mathrm{O}_{2}$ than do GPx and Prdx. Therefore, both GPx and Prdx are the main metabolic pathways for $\mathrm{H}_{2} \mathrm{O}_{2}$ at low concentration, whereas GSH would have a prominent function at higher concentrations of $\mathrm{H}_{2} \mathrm{O}_{2}$ [27]. A kinetical analysis has shown that both Prdx2 and GPx1 are strong sensors of $\mathrm{H}_{2} \mathrm{O}_{2}$ [27].

The nuclear factor E2-related factor 2 (Nrf2) controls the expression of enzymes that participate in the defense against oxidation, although many Nrf2-independent ROS clearance enzymes and nonenzymatic antioxidants also exist [28]. In the presence of normal levels of ROS, the expression of Nrf2 is controlled by the Kelch-like ECH-associated protein 1 (Keap 1), which targets Nrf2 to ubiquitin-mediated degradation in the cytoplasm. In the presence of increased ROS production, the Nrf2 molecule dissociates from Keap 1 and moves into the nucleus, where it binds to the antioxidant-response element (ARE), together with the small MAF transcription factors, in the promoter regions of target genes that encode antioxidant enzymes. Notably, the promoter of the Nrf2 gene itself contains AREs [29] and amplifies the redox cascades via positive-feedback regulation in cancer cells or phase I ligand-responsive cells.

The cytoplasmic aryl hydrocarbon receptor (AhR) protein binds to the ligands that have translocated into the nucleus and activates the expression of a large family of antioxidant molecules, i.e., the cytochrome p450 proteins (CYP1A1, CYP1A2, and CYP1B), in cancer [30], as well as several other antioxidation molecules, such as $\mathrm{NAD}(\mathrm{P}) \mathrm{H}$ quinone oxidoreductase 1 (NQO1), 
after the formation of heterodimers with Arnt. The AhR-dependent increases in neutrophilia and iNOS levels in the infected lung were reported to be mediated by AhR-regulated events extrinsic to bone-marrowderived cells [31, 32]. An experiment using Cre/loxP technology confirmed that AhR-mediated iNOS increases and neutrophil migration to the lung during IV infection [33].

\section{Influenza virus (IV)}

The genomes of IVs consist of negative single-stranded RNAs that are associated with the viral nucleoprotein (NP). They interact with viral RNA-dependent RNA polymerases heterotrimer, i.e., the polymerase basic protein 1 (PB1) and 2 (PB2) and polymerase acidic protein, to build the viral ribonucleoprotein (vRNP) complexes.

Human influenza A virus (IAV) infections generated pandemics in 1918 caused by H1N1, in 1957 by H2N2 and in 1968 by H3N2 [34]. Pandemic IVs cause much higher morbidity and mortality than outbreaks of annual and epidemic IVs. IV infection includes both upper and lower respiratory tract involvement. IV pneumonia resulted in either alone or with secondary bacterial pneumonias. The IV pandemic in 1918 known as worst pandemic on record indicated the death of up to 50 million people globally. However, it was also reported that the spectrum of pathologic alterations shown in the 1918 IVs pandemic does not differ from those of pathological abnormalities on other less-pandemic patients or even in dead patients during seasonal IV outbreaks [35]. One exception is the hypercytokinemia or cytokine storm; one of the possible features proposed to explain the pathogenesis of $\mathrm{H} 5 \mathrm{~N} 1$ pandemic infection [36].

The PB1-F2 protein is expressed from the $\mathrm{PB} 1$ gene of most IAVs, which is localized in mitochondria. It commits apoptosis by interacting with two mitochondrial proteins in host cells [37]. The Ser residue, but not the Asn residue, at position 66 of PB1-F2 is critical for the high pathogenicity of an H5N1 in mice [38]. The 1918 pandemic IVs carried the mutation of the Asn residue at position 66 to Ser in the PB1-F2 protein. The replacement of Ser with Asn attenuated the strong infectivity of the 1918 IVs, which pinpointed the PB1-F2 protein as a critical determinant of viral pathogenicity. PB1-F2 interacts with PB1 and affects the shuttling of this protein between the nuclei and cytoplasm [39], this shuttling ability might be affecting virulence. Thus, the shuttling ability seems to be critical in this context. IAVs attach to host cells via the binding of the hemagglutinin (HA) protein to the sialosaccharides of glycoproteins on the cell surface. The binding specificities of HAs in IVs derived from different host species are different. For example, HAs of human IAVs recognize sialic acid (SA)$\alpha-2,6-$ Gal-terminated saccharides $(\alpha-2,6-\mathrm{SA})$ mainly, whereas HAs of avian IVs preferentially select to bind SA- $\alpha-2,3-$-Gal-terminated saccharides $(\alpha-2,3-S A)$. The horizontal avian-to-human transmission of IVs was abolished by mutations of two amino acids in HA that produced a switch in preferential binding from avian $\alpha$ 2,3-SA to human $\alpha-2,6-\mathrm{SA}$ [40]. The pattern of virus attachment of the two subtypes of human IAVs (H3N2 and $\mathrm{H} 1 \mathrm{~N} 1$ ) and low pathogenic avian IVs (H5N9 and H6N1) was compared with the pattern of viral attachment of avian H5N1, which is highly pandemic [41]. Thus, the recognition pattern of IAVs to HAs might be critical for determining the degree of pathogenicity. However, the sugar-mediated binding specificity of IAVs to HAs varies according to specific viruses, which might hamper the development of new anti-IAV drugs.

In contrast to human IVs, the avian H5N1 virus binds mainly to the alveolar and bronchiolar epithelium, causing the damages in diffused alveolar epithelium as the primary hit. Viremia and extra-respiratory complications seem to be more common in infections with the avian $\mathrm{H} 5 \mathrm{~N} 1$ than with human IVs.

It has been reported that IV infection leads to the induction of oxidative stress or ROS damage and the development of clinical output. The direct clinical use of antioxidation drugs in IV-infected patients has not been reported. In humans, IAV infection increases the levels of metabolites such as 8-hydroxydeoxyguanosine, malondialdehyde, 2-isoprostane, 7-ketocholesterol, 7beta-hydroxycholesterol, and carbonyl compounds in the plasma and urine. The levels of antioxidant enzymes, such as SOD and catalase; cytokines, such as IL-6, 1L10 , and TNF- $\alpha$; and HSPs, such as HSP90 and HSP27 were also increased in H1N1-infected patients [24, 42]. Increased ROS, nitric oxide synthase 2 (iNOS2), and nitrotyrosine levels have been detected in patients and in a mouse model [43]. The results obtained from mouse models and cell lines infected with IVs demonstrated the production of enhanced levels of ROS, together with an imbalance of antioxidant protection [44, 45]. These models indicated the relevance of the redox homeostasis induced by IVs [46-50].

Antioxidation molecules ameliorate ROS damage in IV-infected host cells, whereas ROS enhance the pathogenic ability of IVs $[26,46]$. To examine the role of oxygen free radicals in hosts, SOD conjugated with a copolymer of pyran was administered to mice, in an attempt to decay free radicals; this approach prevented infection with IV in these animals [51]. GSH inhibits the expression of viral matrix proteins, IV replication, and the production of virion particles. Furthermore, GSH suppresses the upregulation of Fas, caspase activation, and apoptosis in infected cells [52]. However, IV infection disrupts the redox balance by decreasing GSH production and promoting the propagation of the virus 
progeny, thus resulting in cell death [53]. The mechanism underlying the IV-induced downregulating of GSH remains unknown.

shRNA-mediated knockdown of Nrf2 decreased the expression of the Nrf2 protein in human nasal epithelial cells, whereas the upregulation of Nrf2 was strongly correlated with viral entry and its replication, indicating an inverse relationship between the levels of Nrf2 expression and susceptibility to IV infection [54].

The activation of the Nrf2/heme oxygenase 1 (HO-1) and Toll-like receptor (TLR)/mitogen activated protein kinase (MAPK)/nuclear factor kappa B (NF- $\mathrm{kB}$ ) signaling pathways is involved in IV replication and IV-related pneumonia [55-57]. In some cases, the AhR also regulates redox genes, such as the NQO1 gene, to maintain the ROS balance in host cells [58]. It is well known that the NQO1 gene is regulated by the ARE, which is mediated by Nrf2 and the small Maf family of proteins [59]. In addition, the NQO1 gene is also regulated by the AhR/Arnt complex, which binds to the Dioxin- responsive element in the NQO1 promoter, in addition to the cytochrome 450 promoters, followed by the detoxification and blockage of the ROS production. Thus, we speculate that the binding of the AhR to the ligand after IV infection induces the oxidation of DNA, protein, and lipid components within cells to produce ROS at a higher level, thus leading to apoptosis and autophagy (Fig. $1[49,60]$;).

In general, AhR induces the detoxifying enzyme cytochrome p450 and the phase II enzyme NQO1 or HO-1, to achieve redox regulation and maintain ROS balance; these molecules contain ARE cis-elements, which are controlled by Nrf2. Thus, the AhR-Nrf2 transcription factor battery plays a key role in the maintenance of ROS balance. In the case of IV infection, this theory might be adopted, as like the case of phase I ligand exposure $[61,62]$.

At the molecular level, IVs induce oxidative stress via AhR pathway in the cytoplasm, especially stresses in the endoplasmic reticulum (ER) and mitochondria, which are followed by the production of ROS. Simultaneously, the AhR transcription factor is translocated into the nucleus to activate the phase I target genes, which encode detoxification enzymes, several antioxidation enzymes, and immunoregulatory and allergy-related genes of antiviral immunity $[10,63,64]$. If the extent of ROS production surpasses the level of antioxidation, the ROS balance was abrogated, and the IV-infected cells commit to apoptosis and necrosis for cell death. If the ROS generation is cancelled by the antioxidation, the redox balance is remained to commit the resistance of host cells to the IV infection and the anti-viral immunity.

Cellular proliferation and apoptosis/necrosis, in addition to the immunity and allergy, are mostly dependent on the ROS balance [65]. Thus, ROS act as bifunctional reactors and exhibit both "good and bad" aspects in living cells, which might be similar in IVinfected host cells and the propagation of IV progeny [66]. These cellular events after IV infection were summarized in Fig. 1b.

\section{ROS, NOS, and RNS production in IV-infected cells}

ROS are defined as chemically reactive species containing oxygen, and RNS are ROS that contain nitrogen instead of oxygen. Increased ROS production, the activation of iNOS2 for RNS production, and increased higher nitrotyrosine levels have been reported in IV-infected patients $[12,67]$. Some of the sources of ROS in IVinfected host cells are summarized below. The generation of iNOS, NO, and 8-nitroguanosine lead to the IV-induced production of the superoxide anion [12, $16,68]$.

\section{PB1-F2 induces ROS production in host cells}

PB1-F2 in influenza type A interacts with the adenine nucleotide translocator and the voltage-dependent anion channel 1 , and inactivates matrix metalloproteinases, releases proapoptotic proteins, and induces cell death [69]. PB1-F2 is involved in the generation of mitochondrial ROS in alveolar epithelial cells by downregulating SOD1 [70]. In addition, H7N9 PB1-F2-induced ROS trigger inflammasome activation and IL- $1 \beta$ secretion, which is inhibited by Mitotempo, an inhibitor of mitochondrial ROS [71]. After viral infections, nucleotide-binding and oligomerization domain (NOD)-like receptor pyrin domain-containing-3 (NLRP3) inflammasomes are activated to induce pyroptosis, a cell death pathway that is inherently associated with inflammation via the activation of caspase- 1 and the secretion of cytokines from infected cells $[70,71]$.

\section{NOX and DUOX protein families}

IV infection can induce cell death through viral PB1-F2, which targets mitochondria. Moreover, this cell death is conserved in IV type A, but not in IV type B [69]. In addition to the mitochondrial respiratory complex, ROS generated from NOX are involved in the pathogenesis of IV infection. The NOX family is found in cell and phagosome membranes, and comprises several members: NOX1 to NOX5, DUOX1, and DUOX2 [72]. The NOX family is expressed in cell-type-specific manner and is critical for the infection permissiveness of IV [72]. NOX1 is expressed in epithelial cells in the colon, placenta, prostate, and uterus, as well as in vascular smooth muscle cells, astrocytes, microglia, neural cells, and retinal pericytes. NOX2 is detected in cardiomyocytes, the endothelium and coronary microvascular endothelial cells, phagocytes, granulocytes in the umbilical vein, 

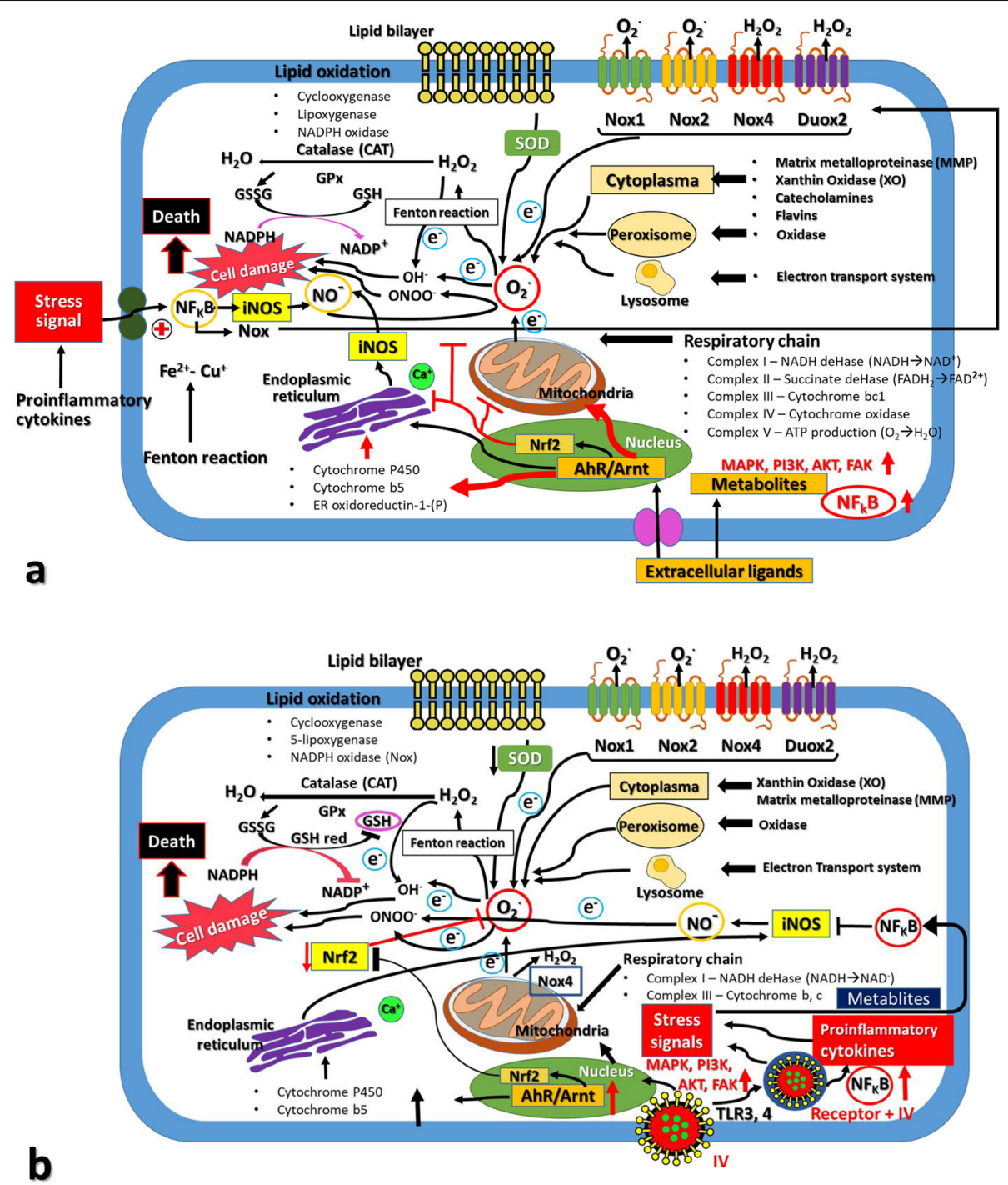

Fig. 1 Schematic representation of ROS/RNS production and Redox control in response to stresses inducing reagents and influenza virus (IV) infection. Subcellular organelles and cellular components were affected by the oxidation and antioxidation responses in the case of stress inducers like phase I reagents and environmental hormones (Panel $\mathbf{a}$ ) and infection of IVs (Panel $\mathbf{b}$ ). The source of cellular ROS/RNS production mainly occurred in mitochondria, endoplasmic reticulum, lipid bilayer, organelle membranes, cellular lipids, DNA in the nuclei, and cellular oxidation enzymes and antioxidation enzymes such as superoxide dismutases (SODs), catalases (CATs), peroxidases (Prdxs), glutathione peroxidase (GPx) and glutaredoxins (GRs) and so on. In addition, the cellular signaling pathways such as NF-kB, MAPK, PI3K, AKT and iNOS signaling are also shown. After IVs infection, NOX produced superoxide $\left(\mathrm{O}_{2}{ }^{-}\right)$and dysfunction on the mitochondrial proteins. The defective mitochondrial proteins resulted in the leakage of electrons and superoxides from the mitochondria, as well as initiating cell death pathways by cytochrome c or permeability transition pore (PTP). The NF-kB produced many cytokines as well as inducible nitric oxide (NO) synthase (iNOS). This iNOS then produced nitric oxides (NO). The $\mathrm{NO}$ and $\mathrm{O}_{2}{ }^{-}$reacted together to produce peroxynitrite $(\mathrm{ONOO})$ which is a highly reactive compound to generate the protein nitration and damage of macromolecules. and viral mutations. Higher generation of $\mathrm{O}_{2}{ }^{-}$resulted in the production of $\mathrm{H}_{2} \mathrm{O}_{2}$ by the catalytic activity of SOD. Uncontrolled production of $\mathrm{H}_{2} \mathrm{O}_{2}$ produced hydroxyl radicals $\left(\mathrm{OH}^{-}\right)$via reaction with metal cations, and these $\mathrm{H}_{2} \mathrm{O} 2$ and $\mathrm{OH}^{-}$caused irreversible damages to cellular proteins, lipids, nucleic acids and so on. This Figure is a modified version of the ones published by Di Meo et al. [16] and Kohmich et al. [46].

fibroblasts, hepatocytes, hematopoietic stem cells, neuronal cells, and vascular cells in skeletal muscles. NOX3 is expressed in the fetal kidney, liver, lung, and spleen and, at lower levels, in the adult colon and kidney. NOX4 is expressed in the eye, kidney, liver, lung, and ovary, as well as endothelial cells, fibroblasts, keratinocytes, mesangial cells, neurons, osteoclasts, and smooth muscle cells. NOX5 is expressed in mammary glands and the cerebrum, heart, kidney, liver, lung, lymphoid tissue, prostate, skeletal muscle, spleen, testis, and thymus, as well as vascular smooth muscle cells. Both DUOX1 and DUOX2 are detected in the colon, 
cecum, duodenum, floating colon, ileum, jejunum, pancreas, pancreatic islets, prostate, rectum, stomach, thyroid, sigmoidal colon, and the tracheal and bronchi epithelium [44, 72-74].

Upregulation of $N O X$ and downregulation of SOD1, SOD3, Nrf2, and CAT were reported in H5N1-infected A549 cells [53]. Infection with H5N1 decreases SOD1 promoter activity, whereas the overexpression of SOD1 disrupts H5N1 virus replication in A549 cells.

\section{NOX2 in lung alveolar epithelial cells}

NOX2 seems to be involved in the production of ROS during IV infection $[13,75]$. In a mouse model, Nox2derived superoxide is critical for IV-induced pulmonary damage. Nox $2^{-/-}$knockout (KO) mice exhibited a milder airway inflammation and less apoptosis in the alveolar epithelium after IV infection than did wild-type mice [75]. The IV-mediated production of ROS and RNS was also decreased in $\mathrm{Nox}^{-/-} \mathrm{KO}$ mice [75]. In another study, the titer of active competent viruses and their associated inflammatory activities were decreased in these $\mathrm{KO}$ mice [72]. These findings suggest that NOX2 is a candidate for anti-ROS treatment to manage IV infection [75].

\section{NOX4 in lung epithelial cells}

NOX4 plays a role in ROS production in lung cancer and in IV-infected primary epithelial cells [44]. NOX4 induces both death and survival in tumor necrosis factor alpha (TNF- $\alpha$ )-challenged cerebral microvascular endothelial cells derived from newborn piglets. TNF- $\alpha-$ induced NOX4 activation causes oxidation-related cell death. Concomitantly, NOX4-derived ROS initiate the carbon monoxide (CO)-mediated survival of cells through the activation of heme oxygenase-2. CO prevents NOX4 activation, decreases oxidation, and ultimately promotes the survival of brain endothelial cells through the AKT signaling pathway. Moreover, $\mathrm{CO}$ inhibits TNF- $\alpha$-induced ERK1/2 and p38 MAPK in an AKT-dependent manner. These findings suggest that NOX4 is a key element in the ROS-controlled survival of endothelial cells during TNF- $\alpha$-mediated brain inflammation [76].

\section{NOX1 in bronchoalveolar lavage fluid-derived fibroblasts}

The production of superoxide anion in bronchoalveolar lavage fluid-derived fibroblasts from H3N2-infected Nox $1^{-/-}$KO mice was inhibited at day 7 after infection, although it did not differ from that observed in wildtype littermates at day 3 after infection (in the early stages of infection) [77]. Mice expressing an inactive Nox1 $\left(\right.$ Nox $\left.1 \%^{*} / \gamma\right)$ exhibited a higher survival rate after an influenza type A virus challenge than did control mice [78] [76]. The adaptive immune response was altered after the IV challenge in these mice, as shown by a decrease in the number of virus-specific CD8+ T cells in the lung, an increase in the number of virus-specific CD8+ $\mathrm{T}$ cells expressing CD127 (IL-7 receptor) in the lung, and draining of lymph nodes. These findings suggest that Nox1 negatively affects the early adaptive immune response to IV infection.

\section{DUOX2 in the human nasal epithelium and mouse nasal mucosa}

DUOX2 is another source of ROS production during IV infection [79, 80]. IV infection stimulates the induction of DUPX2/DUOXA2 and a moderate reduction of DUOX1 expression [77]. This DUOX2/DUOXA2 induction occurred after H1N1, but not after H3N2, infection [77]. In the human nasal epithelium and mouse nasal mucosa, DUOX2-induced ROS formation was triggered in airway cells via the type 1 and type 3 interferon (IFN) pathways, which induced the RIG-1-like receptor double-stranded RNA helicase enzyme (RIG-1) and the melanoma-associated differentiation gene 5 (MDA5) [81]. The increase in ROS production in mitochondria mediated by DUPOX2 or NOX2 is indicative of mitochondrial dysfunction [82].

\section{ROS in IV-induced tissue injury and cell death}

Viral infection may alter redox control and pathophysiology and the antioxidation machineries. For example, Lin et al. reported that infection with $\mathrm{H} 5 \mathrm{~N} 1$ results in a higher level of ROS in A549 cells compared with infection with $\mathrm{H} 1 \mathrm{~N} 1$ and is accompanied by a significant reduction in the ratio of reduced glutathione (GSH) to oxidized glutathione (GSSG) [53].

\section{IV-induced cell injury in the lung}

In humans, IV infection causes a contagious respiratory disease in which many alterations of biological functions are induced, such as apoptosis and necrosis [83], autophagy [84], inflammation [85], lung injury (LI) [86], DNA damage and oxidation in host cells [87], lipid peroxidation [88], and ROS production in mitochondria [10].

Oxygen radicals are produced in the lungs of mice infected with IV [89] and ROS play a critical role in the acute lung injury (ALI) that occurs in mice infected with the highly pathogenic avian IV type A (H5N1) [90]. Moreover, in some cases, infection with H5N1 induced a high viral load and a strong proinflammatory reaction [36]. This action of H5N1 increases mortality and generates a more pronounced oxidative stress compared with other IVs, such as the human influenza A virus (H1N1).

Recent studies have reported that ROS production exerts a positive or negative effect during IV infection [91]. In the former case, viral infection can generate moderate ROS levels, which play a critical role in biological 
reactions with few cellular damage events. In contrast, excessive ROS are the major cause of LI. Downstream ROS targets, such as NOX1, NOX2, NOX4, and DUOX2, are involved in apoptotic cell death in the epithelium and ALI [46, 77]. After infection, IVs hijack the biological functions of host cells to enhance viral replication [24]. Accordingly, the imbalance between the redox control against IV and the production of excess ROS results in tissue damage [46].

\section{Effect on the nervous system}

IVs damage the central nervous system (CNS), leading to IV-associated encephalitis and encephalopathy [92]. Previous studies have suggested that IVs can infect astrocytes, which are the most abundant cells in the CNS and an integral part of the blood-brain barrier and induce a proinflammatory cytokine response and apoptosis [93, 94]. Lin et al. reported that human astrocytes induced the expression of CXCL9-11, NF-KB, and p38MAPK phosphorylation, as well as receptors of neurotransmitters, such as the melanocortin 2 receptor, cholinergic receptor nicotinic gamma subunit, purinergic receptor, gamma-aminobutyric acid (GABA) A receptor $\alpha 1$, and epidermal growth factor receptor 2, which are involved in synaptic transmission and CNS disorders [95]. More recently, it was reported that H5N1 bound and cleaved HA with a specificity for alpha-2,3-linked sialic acids, allowing the efficient binding of IVs and their efficient replication in CNS cells [96, 97]. Most of these reports are restricted to $\mathrm{H} 5 \mathrm{~N} 1$, except for one human H1N1 study [94, 95].

\section{IV-mediated ROS on cellular components}

These IV-mediated functions, such as the effects on TLR family members, inflammation, matrix metalloproteinases (MMPs), and ER stress, in host cells are triggered, at least in part, by the regulation of Nrf2/ROS signaling and the signaling pathways of PI3K/AKT, p38/JNK MAPK, and NF-kB.

\section{TLR family and membrane receptors}

Human IV infections, such as H1N1 and H3N2, increase the expression of TLR family members, including TLR3, 7, 8, and 9; however, TLR2 and 4 are suppressed in this setting [98]. Another report showed that the expression of TLR2, 3, and 9 was correlated with H1N1 infection [99]. The upregulation of signaling molecules of IkB, P-MAPKs, and inflammatory cytokines (such as IL-6, sTNFR-1, MCP-1, CXCL10, and IFN gamma) is closely related with the upregulation of TLRs, MyD88, IRAK4, and TRAF6 and with human, avian, and swine IVs [57, 99-101].

$\mathrm{Tlr}^{-/-} \mathrm{KO}$ mice exhibit higher survival rates with lower viral titers, lower production of mediators of inflammation, and fewer pathological alterations in their lungs after IV infection than their wild-type counterparts $[102,103]$. TLR7 is also required for the efficient replication of IVs [104]. The inhibitors of the TLR7/8-MyD88 axis possibly also inhibit IV replication and control proinflammatory cytokines and MMPs [105]. In contrast, the expression levels of TLR4 determine H1N1 entry and infection tropism via MyD88-p38 MAPK signaling [106]. Inactivated avian H5N1 can rapidly lead to the activation of the TLR4/TRIF/TRAF6/NF- $\mathrm{kB}$ axis [11]. $T l r 4^{-/-}$KO mice are refractory to H1N1-induced ALI, and a TLR4 antagonist decreases H1N1 viral titer and its lethality [107].

\section{ROS controls pattern-recognition receptors (PRRs)}

The recognition of self and nonself in the innate immune reaction is carried out by pattern-recognition receptors (PRRs), which are the germline-encoded receptors located on the plasma membranes and within endosomes [108], that act as sensors to monitor infection. PRRs can sense an exogenous pathogen-associated molecular patterns (PAMPs) and endogenous dangerassociated molecular patterns (DAMPs). DAMPs include ROS, heat-shock proteins, oxidized lipoproteins, and cholesterol. DAMPs can trigger innate inflammation by binding to PPRs, including TLRs, NOD-like receptors (NLRs), retinoic acid-inducible gene (RIG)-I-like receptors, and absent in melanoma (AIM) 2-like receptors (ALRs) [105]. The interaction with these receptors can amplify the inflammatory responses in the host cells. The innate immune receptors might modulate oxidative phosphorylation in mitochondrial function. Thus, oxidative stress responses can regulate PPRs for ROS/RNS mediated molecular targets.

In addition, the mucosal defenses of the lungs against IAVs can be followed by a single inhaled treatment comprising a synergistic combination of a TLR agonist (such as the diacylated lipopeptide ligand of TLR2/6, Pam2CSK4) and a CpG ligand for TLR9 (ODN362). These antiviral responses to viral burden attenuated the infectivity and enhanced survival potency via the protective responses afforded by ROS generation [109]. The interaction with these receptors can amplify the inflammatory responses in the host cells. The innate immune receptors might modulate oxidative phosphorylation in mitochondria. Thus, oxidative stress responses can regulate PPRs for ROS/RNS-mediated molecular targets.

\section{Matrix metalloproteinases (MMPs)}

H3N2 infection induces the expression of MMP-9, but not of MMP-2, in Vero cells. MMP-2 production is increased in Madin-Darby canine kidney (MDCK) cells. Thus, the induction of MMPs is dependent on the epithelial cell type [110]. The expression of MMP-9 is 
increased in the lungs of a mouse model of IAV infection [111]. The immunopathological response to IV strains via the production of MMP-9 was compared between the human IV viruses H1N1 and H3N2 in mice and revealed that $\mathrm{H} 1 \mathrm{~N} 1$ induces high mortality and severe lung changes with Gr1+ and CD11b+ cell infiltration and upregulation of CXCL6/GCP-2, CCL2/MCP-1, and the tissue inhibitor of metalloproteinase 1 [112]. Infection with H1N1 upregulated the active and latent forms of MMP-9 in the lung and an inhibitor of MMP-2 or MMP-9 reduced in lung pathology partially. Both Gr$1+$ and $\mathrm{CD} 11 \mathrm{~b}+$ cells in H1N1-infected lungs produced ROS and RNS, indicating that MMP expression is controlled by oxidation and antioxidation. The human influenza type A virus induced the infiltration of neutrophils, which produced MMP-9 [113]. In contrast, MMP-9 production was not increased in human neutrophils after IV type A infection [114]. Thus, MMP-9 production in neutrophils is not controlled by IVs per se. Other cell types, such as macrophages, might regulate IV-mediated MMP-9 production. H1N1 induced the expression of the MMP-9 gene and the cleavage of pro-MMP-2 into an active intermediate protein in human fetal membrane cells, resulting in the weakening of membrane integrity and the degradation of the extracellular matrix [115].

\section{Potential interaction with inflammasomes}

The inflammasome complex is involved in the inflammation-reaction-mediated sensing of microbial and viral components, and endogenous antigens [116]. At least two major types of inflammasomes, i.e., intracellular NLR family and the interferon-inducible protein absent in melanoma 2 (AIM2)-like receptor (ALR) family, have been identified [117]. Mitochondrial proteins are involved in the NOD-NLR family, and pyrin domain-containing 3 (NLRP3) inflammasome regulation [118]. Pathophysiological changes were observed in mitochondria, including the imbalance of mitochondrial dynamics, cytochrome c secretion, mitochondrial DNA damage, or ROS production, which can either activate or inhibit the NLRP3 inflammasome [119]. NLRP3 was activated by exogenous ligands such as PAMPs, including bacterial toxins, and by endogenous stimuli derived from the host, such as damage-associated molecular patterns. Upon IAV infection, the mitochondrial fusion protein mitofusin 2 can regulate the activation of the NLRP3 inflammasome [120]. The IAV PB1-F2 protein, which is translocated to mitochondria, can cause mitochondrial fission associated with the defective NLRP3 inflammasome [121]. However, there is not sufficient information regarding how dynamin-related protein 1 (DRP1)-mediated mitochondrial fission is generated in the innate immune signaling in IAV-infected cells. Swine IV (SIV) infection resulted in NLRP3 inflammasome activation, leading to IL-1 $\beta$ production in primary porcine alveolar macrophages (PAMs) [122]. Furthermore, upon SIV infection of PAMs, mitochondrial fission occurred through the RIPK1/DRP1 axis, which acted on the NLRP3 inflammasome-regulated production of IL-1 $\beta$ [123]. IAV produced endogenous ROS via NOX2-containing NOXs and mitochondria, to circumvent anti-IAV responses. These evolutionarily conserved processes were enhanced by glycolysis, the pentose phosphate pathway, and the tricarboxylic acid (TCA) cycle, which drove inflammation. These metabolites involved succinate, which stimulated the inflammation reaction through the ROSmediated stabilization of hypoxia-inducible factor- $1 \alpha$, promoting production of interleukin- $1 \beta$ by the inflammasome. In addition, itaconate was investigated for its role as an anti-inflammatory and antioxidant metabolite of the TCA cycle [124]. NLRP3 inflammasome activation by decreased ROS through mitophagy might play a crucial role in berberine (BBR)-mediated alleviation of IV-induced inflammatory lesions [125].

\section{Inflammation and ER stress}

IV infection induces a robust production of cytokines, such as IFNs; interleukins (ILs); chemokines, such as CXCL10 and CCL5; tumor necrosis factors (TNFs); and ROS, which can promote the expression of inflammatory cytokines [126]. The generation of ROS is required in host cells after the activation of TLRs, which may be used by IVs to promote innate immunity functions in their hosts [11]. IVs trigger the production of proinflammatory cytokines/chemokines, such as CCL5/RANTES, CXCL10 (C-X-C motif chemokines), IL-1 $\beta$, IL-6, IL-8, and TNF- $\alpha$ [127]. Some of these factors belong to the NF- $\mathrm{B}$ signaling pathway, including IL-2, IL-6, IL-8, MIP1a, MCP-1, and RANTES [126]. These issues were reviewed by other authors $[10,128]$.

After IVs infect the host cells and the production of ROS/NOS surpasses the normal levels, events such as the production of oxidizing nitrogen oxides and peroxynitrite occur concomitantly. In turn, these events induce the oxidation or nitration of amino acid residues, lipid peroxidation, and DNA strand breaks, finally producing apoptotic signals in states of ER stress or of oxidative stress in mitochondria [129]. Thus, the generation of ROS is related to the cascades that commit the ER and mitochondria to apoptosis.

IV infection also induces ER stress and generates ROS in inflamed tissues [83, 129]. IVs induce proteasomedependent ER-associated degradation through the inositol-requiring enzyme $1 / \mathrm{x}$-box binding protein 1 (IRE1/XBP1) signaling pathway and commitment to downregulation of SOD1, thus allowing ROS accumulation. ROS-mediated JNK or the IRE1-mediated JNK1 contributes to the control of IV infection and 
propagation [129]. H1N1 PR8 infection of mouse tracheal epithelial cells increased the ER-stress-related ATF6 and the ER chaperone Erp57 [130]. IV infection induces caspase 12 to commit to apoptosis, as well as the production of TGF- $\beta$ in IV-infected cells in a JNK1dependent manner [130]. H1N1-infected mice exhibit induction of parenchymal lung inflammation, alveolar epithelial metaplasia, and ER stress. A lung epigenetic/ transcriptome analysis demonstrated that mir-155 null mice recovered from IV infection and exhibited decreased lung inflammation and ER stress [131]. Protein disulfide isomerase 3 (PDIA3) interacts with IAV-HA, and this interaction is critical for the efficient oxidative folding of HA in vitro. PDIA3 is upregulated in IAVinfected mouse or human lung epithelial cells and interacts with IAV-HA directly. Treatment with a PDI inhibitor, LOC14, inhibited PDIA3 enzyme activity in lung epithelial cells, followed by the reduction of intradisulfide bond and subsequent oligomerization (maturation) of HA in both H1N1- and H3N2-infected lung epithelial cells [132]. IAV-mediated autophagy and unfolded protein response are connected to apoptosis in chronic stresses to regulate cellular homeostasis via $\mathrm{CHOP}$ and Beclin-1 [133].

\section{Lipid oxidation}

Malondialdehyde, F2-isoprostane, 7-ketocholesterol, and $7 \beta$-hydroxycholesterol have been identified as lipid alterations that are induced by IV-mediated ROS [24, 42]. IV infection induces oxidation, which is accompanied by an increase in the levels of lipid peroxidation in the presence of vitamin E, conjugated dienes, and total malondialdehyde [134]. IV-infected cells or animals exhibit increased oxidation of free radicals in unsaturated lipid chains in the host membranes, which decreases their permeability. In the absence of antioxidants, the cell membranes are severely damaged and ultimately exhibit severe pathological changes [135]. A/Aichi/2/68 IV infection increased the levels of lipid peroxidation (conjugated dienes and total malondialdehyde) and decreased the levels of endogenous natural antioxidant vitamin E. Supplementation of mice with exogenous vitamin E before viral infection protected the lungs and blood against lipid peroxidation damage [134].

\section{DNA oxidation in host cells}

DNA is the most common target of ROS, which they modify to give, for example, $8^{\prime}$-hydroxy-2' -deoxyguanosine $(8-\mathrm{OHdG})$ at the 8 -position of $\mathrm{dG}$ in the host DNA. 8-OHdG is produced via a transversion mutation of $\mathrm{G}$ to $\mathrm{A}$ in the host DNA and increases the risk of neoplasia [136].

\section{Cellular signaling mediated by IV-induced ROS}

The triggering of these functions by IV is related to ROS generation and associated redox regulation.

\section{Nrf2 signaling pathway}

Redox homeostasis is maintained by cellular enzymes such as SODs, CAT, and GPx, which participate in antioxidant defense systems. IV infection can decrease the production of antioxidation targets, such as HO-1 and NQO1, SOD1 [53, 137], GR, CAT, and GPx1 [138] are downstream molecules of the Nrf2 pathway after IV infection. Thus, Nrf2 plays an important role in redox regulation upon IV infection [28, 49, 54, 139-141]. IVs activate the Nrf2/ARE antioxidation pathway via Nrf2, followed by the transcriptional activation of Nrf2 target genes, such as HO-1 and HMOX1 [140, 142].

The highly pathogenic avian H5N1 IV reduces the levels of phosphorylated Nrf2 in the nucleus and downregulates the expression of fibronectin to a greater extent than does the human H1N1 IV [143]. Several studies found no changes in the levels of SOD in IVinfected cells [135]; however, other studies found a contradictory lower level of SOD1 caused by protease degradation [52, 144]. Increased expression of SOD1 was reported in patients with asymptomatic IV infection [145]. Decreased levels of SOD1 have been found in children infected with H1N1 [146]. Therefore, whether SOD1 is a marker of IV infection remains uncertain.

Similar controversial findings have been reported for other antioxidant enzymes, such as CAT and indolamine-2,3-dioxygenase (IDO). IDO scavenges superoxide anion for oxidation or for converting tryptophan into kynurenine [147]. The IDO level is unaltered and the CAT levels are reduced in IV-infected cells in vitro [135]. In contrast, in infected mice, both IDO and $\mathrm{HO}-1$ are induced, and CAT is unchanged [148]. Cat- peroxiredoxin-6 (Prdx6-)-deficient mice infected with H1N1 exhibit depletion of IV-permissive bronchial Clara cells and/or alveolar type 2 cells [142]. Similar reports showed the induction of other enzymes, such as GPX3 and HO-1. Other Nrf family members, such as Nrf1, bind to the ARE in the promoter regions of redoxrelated genes, although to a lesser extent than that observed for Nrf2. In contrast, Nrf3 does not behave similarly [149].

\section{The p38 MAPK signaling pathway}

p38 MAPK plays a vital role in cell proliferation, differentiation, development, and death. For example, phosphorylated p38 is translocated into the cell nucleus and upregulates cytokines/chemokines under oxidative stress. In $\mathrm{Bcl}-2+$ cells (MDCK introduced by $\mathrm{Bcl}-2$ ), p38MAPK interacts with $\mathrm{Bcl}-2$ and colocalizes in the cytoplasm, and both Bcl-2 phosphorylation and 
apoptosis are decreased by specific p38MAPK activity. In contrast, in $\mathrm{Bcl}-2$-negative $\left(\mathrm{Bcl}-2^{-/-}\right)$MDCK cells, which are fully permissive to viral infection, p38MAPK activity is present in nucleus predominantly, and its inhibition reduces the traffic of vRNP and the phosphorylation of viral nucleoproteins, suggesting that p38MAPK contributes to the regulation of vRNP export and viral replication [150]. Amatore et al. reported that IV infection upregulates NOX4 and that the NOX4-derived ROS activate $\mathrm{p} 38$ and ERK1-2 MAPK, which in turn promote the nuclear export of vRNP and consequently lead to viral replication [44]. Thus, p38MAPK might be related to the vRNP export by phosphorylation and viral replication. Curcumin inactivates IAV directly, and inhibits IAV adsorption and replication; moreover, its inhibition of IAV replication may occur through the Nrf2 signal, to inhibit the IAV-induced activation of the TLR2/4, p38/ JNK MAPK, and NF- $\mathrm{kB}$ pathways. Thus, inactivation of p38/JNK MAPK, NF-kB and TLR2/4 exerted antiinfluenza virus effects. p38/ JNK MAPK is a critical mediator of oxidation-induced apoptosis, to increase ROS and COX-2 production [151].

\section{The NF-KB signaling pathway}

NF- $\kappa B$ plays a key role in the activation of the immune system. The NF- $\mathrm{kB}$ complex comprises five proteins, namely Rel A (p65), c-Rel, Rel B, p50, and p52. The NF$\kappa B$ p50/p65 heterodimer associated with I $\kappa \alpha$ is related to the outcome of oxidative stress [152, 153]. After phosphorylation of p65 at Ser 276, NF- $\mathrm{kB}$ antagonizes Nrf2 and suppresses the transcription of ARE-dependent genes by recruiting histone deacetylase 3 to the ARE [153]. Thus, inhibition of NF- $\mathrm{kB}$ activity may benefit Nrf2-mediated antioxidation and the suppression of IVinduced inflammation.

Cells treated with the focal adhesion kinase (FAK) inhibitor Y15 or expressing dominant-negative FAK kinase show a reduction in the H1N1-induced NF-kB promoter activity. The nuclear localization of NF-kB is reduced in cells expressing dominant-negative FAK kinase [154]. The human parainfluenza virus type 2 phosphoprotein (P) is a key component of viral polymerase. The $\mathrm{P}$ gene encodes both $\mathrm{P}$ and accessory $\mathrm{V}$ proteins via specific gene editing. Moreover, the nucleocytoplasmic shuttling of the $\mathrm{P}$ protein appears to be important for efficient viral polymerase activity [155].

The H3K79 methylation is critical for IV replication. The downregulation of the H3K79 methylase Dot1L causes a decrease in the nuclear localization of the NF$\mathrm{kB}$ complex, to reduce the antiviral response [156].

\section{The PI3K/AKT signaling pathways}

IVs can modulate several oxidative-stress- and redoxactivated signaling pathways, such as those involving
NF-кB, MAPK, and PI3K/AKT [150, 157-159], to promote viral replication and pathogenesis [32, 150, 160162]. Therefore, the modulation of these signaling pathways may attenuate IV-induced pulmonary damage.

\section{Activation of AhR augments IV virulence}

TCDD-treated and IV-infected mice exhibit activation of AhR in the lungs and a decrease in survival, which suggests a relationship between the susceptibility to viral respiratory infections and exposure to environmental toxin ligands [32]. In this model, increased iNOS levels in endothelial cells of virus-infected mice and an increased number of neutrophils around pneumocytes are observed after AhR activation, which requires a nuclear transport signal and intact DNA-binding domains within AhR [33]. The activation of the AhR, which occurs via kynurenine mediation, regulates the production of IFN $\beta$ negatively after IV infection, which allows virus propagation [163]. IV infection can increase kynurenine production by upregulating the expression of indoleamine-2,3-dioxygenase (IDO1), which is a key enzyme in the kynurenine biosynthesis pathway [164].

In addition to the increased pulmonary neutrophilia and iNOS levels resulting from IV infection, mice treated with TCDD, which activates AhR only transiently, exhibit a diminished IV-specific $\mathrm{CD}^{+}{ }^{+} \mathrm{T}$-cell response [60]. This suggests that the prolonged AhR activation induced by the environmental pollutant TCDD correlates with increased respiratory IAV infection. Furthermore, Boule et al. [165] compared the effects of four AhR agonists, TCDD, 3,3',4,4',5-pentachlorobiphenyl-126 (PCB126) 2-(1H-indol-3-ylcarbonyl)4-thiazolecarboxylic acid methyl ester (ITE), and FICZ, on the immune response in mice infected by IVs. Treatment with TCDD, PCB, and ITE decreased the virusspecific IgM/IgG levels and the number of helper $\mathrm{T}$ cells and $\mathrm{CD}^{+}$cytotoxic $\mathrm{T}$ cells but increased the number of regulatory $\mathrm{T}$ cells. However, FICZ alone decreased the levels of virus-specific IgG and the $\mathrm{CD}^{+} \mathrm{T}$-cell response and increased the number of helper $\mathrm{T}$ cells. These studies suggest that harnessing AhR activity is critical for modulating the host cell immunity to IV infection. Dendritic cells (DCs) were another target [166]. Gene expression studies revealed changes in Lrp1, Itgam, and Fcgr1 expression, as well as alterations in genes that regulate the migration of DCs, and antigen processing/ presentation disrupted by inappropriate AhR signaling during development. These studies suggest the importance of the AhR activation during development in DCs. Franhini et al. reported the genome-wide transcription map of AhR targets genes induced by influenza virus H3N2 in dendritic cells and found that the lectin receptor Cd209a (DC-SIGN) and chemokine the Ccl17 are novel AhR target genes [167]. 

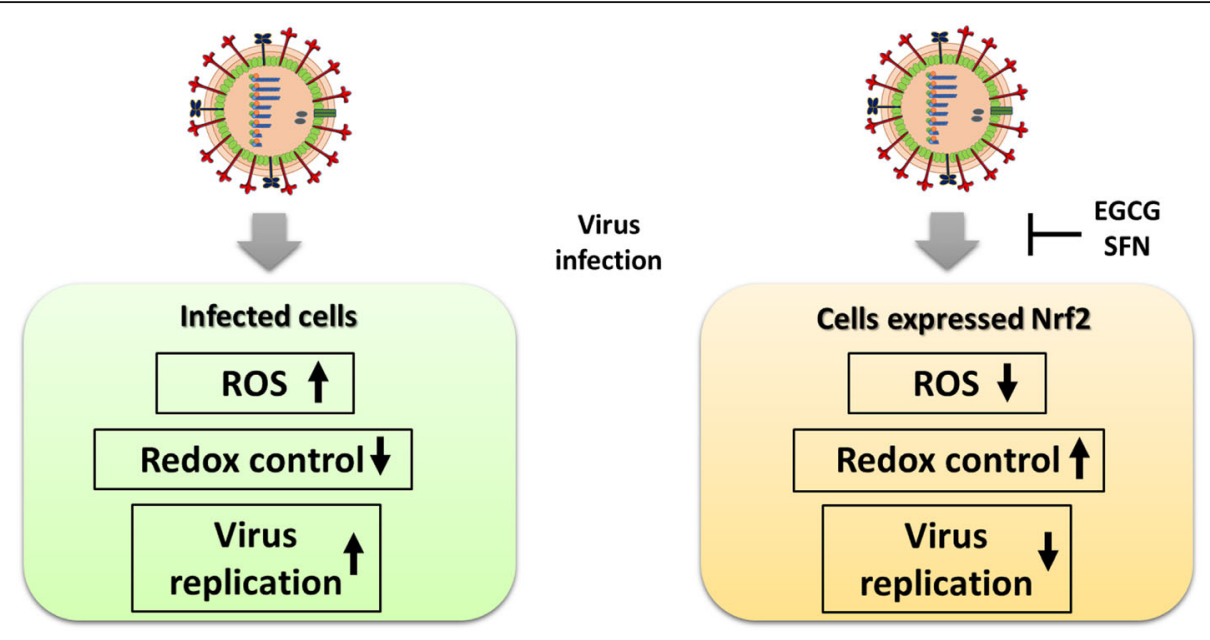

Fig. 2 Model of infection by influenza viruses of normal host cells and cells overexpressing Nrf2. Infection by IVs led to the production of reactive oxygen species (ROS). Redox control against ROS and viral replication are illustrated. The addition of sulforaphane (SFN) or epigallocatechin gallate (EGCG) inhibits the viral infection of IV via activation of the antioxidation pathway [54].

Regarding ROS production and AhR activity in vivo, although singlet molecular oxygen $\left({ }^{1} \mathrm{O}_{2}\right)$ is not fully characterized in mammals, its role is well established in plants, bacteria, and fungi. Although the mammalian enzyme myeloperoxidase mediates the production of ${ }^{1} \mathrm{O}_{2}$, its physiological role in mammals (other than photosensitization of the skin by the UVA component of solar radiation) has not been established [168]. A recent report by Stanley et al. [169] showed that ${ }^{1} \mathrm{O}_{2}$ plays a critical role in redox regulation in atrial relaxation and in controlling blood pressure in mammals during inflammation accompanied by endothelial IDO1 expression. Thus, ${ }^{1} \mathrm{O}_{2}$ is an important ROS in the fields of biology and medicine.

\section{Possible anti-influenza therapies}

During the IV infection, the cellular metabolism of host cells could be affected, leading to a dysregulation of redox homeostasis. IV viruses induce oxidative stresses via the increase in ROS generation and the alteration of ROS scavenging systems. As part of the antioxidation defense, selenoproteins, such as GPXs and thioredoxin reductases (TXNRDs), which are present in the ER, play a critical role in controlling oxidative stress [170]. Antioxidant therapies have been proposed to decrease viral load and to counteract the lung injuries caused by the overproduction of ROS induced by the viruses [171]. Some antioxidants are effective in this protection against infection through the Nrf2 pathway [49]. Antioxidant genes, which can be upregulated by Nrf2, play a critical role in the elimination of ROS/RNS; therefore, enhancement of Nrf2 activity and inhibition of AhR activity have been proposed as approaches to ameliorate the IVassociated pathology. For example, the downstream target of Nrf2, SOD conjugated with a copolymer of pyran, was administered in an attempt to decay free radicals; this approach prevented infection with IV in mice [51]. In this section, antioxidation drugs aimed at inhibiting ROS levels will be reviewed as potential therapeutics for IV infection.

\section{Inhibition of AhR activity}

AhR activation during IV infection disrupts host immunity and causes increased lung inflammation and mortality in mice $[42,64,165,172]$. The suppression of AhR activity is assumed to attenuate IV-induced lung damage. The level of IV-induced IFN $\beta$ is increased in AhR-deficient cells and mice, thus leading to the suppression of viral replication [64]. Several AhR antagonists, such as $\mathrm{CH}-223191$ and Stem Regenin 1, have been identified; however, their therapeutic value against IV-infection-induced LI is unclear. Because AhR responds differentially to diverse intrinsic and extrinsic ligands and affects multiple types of immune cells [172], a careful examination of the advantages and disadvantages of these AhR antagonists is required to assess their value in the treatment of IV infection.

\section{$\mathrm{N}$-acetyl L-cysteine (NAC)}

NAC is a precursor of intracellular cysteine and GSH in mammals. NAC contributes to the resistance against IV infection through mechanisms that include the inhibition of IV replication, the production of proinflammatory cytokines, and the prevention of IV-induced apoptosis [173-176]. NAC suppresses viral replication and the expression of IV-mediated inflammatory factors, such as TNF- $\alpha$, IL- 6 , and IL- $1 \beta$, and then suppresses the inflammation induced by the highly pathogenic avian 


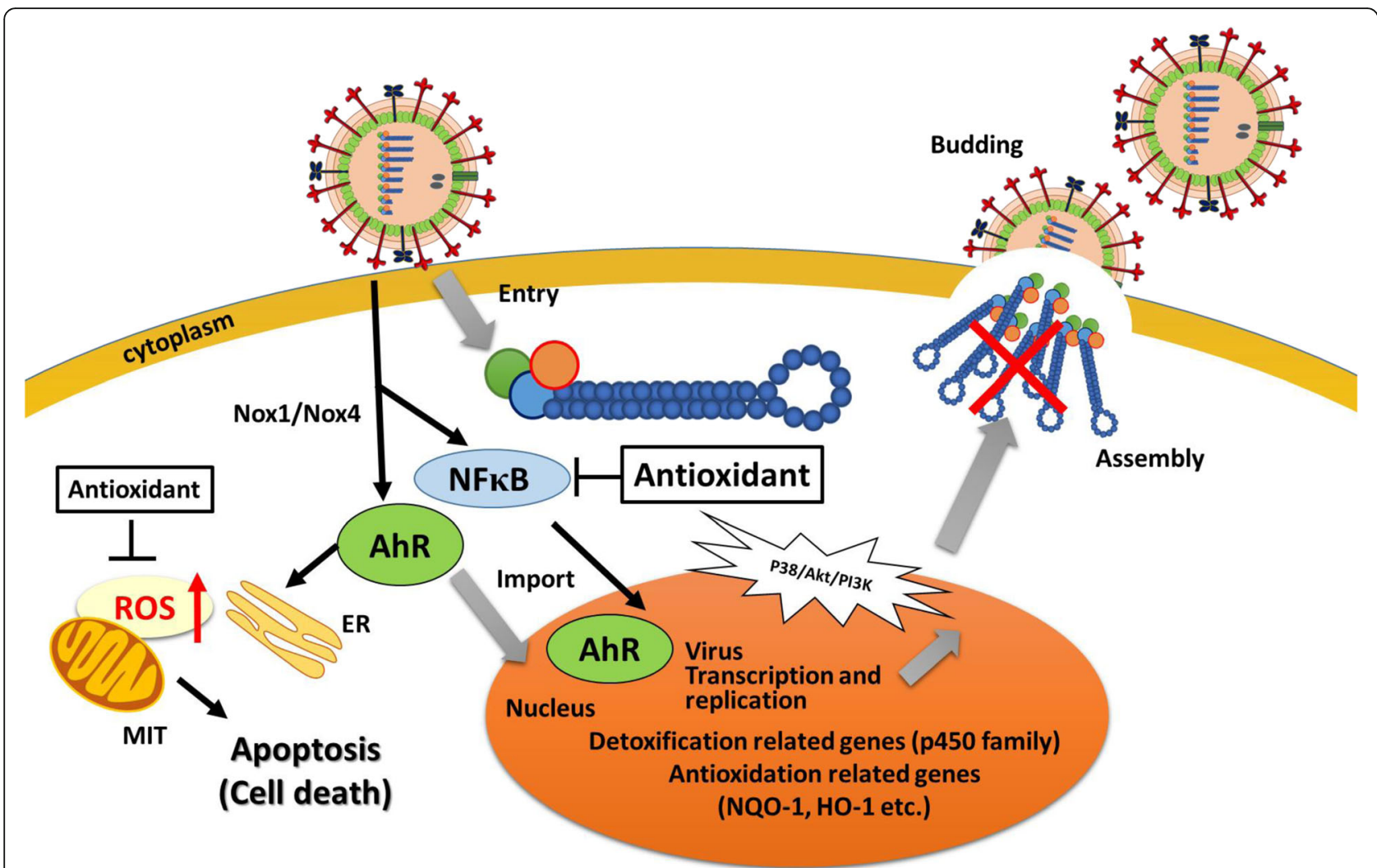

Fig. 3 Schematic model of the mechanism of ROS production and antioxidation during infection with IVs. During the life cycle of the IV, infection causes oxidative stress reactions in host cells, which leads to induction of Nox1/Nox4 and AhR and the production of ROS, followed by replication of the viruses. Nrf2 and other signaling molecules, such as p38, AKT, and PI3K, are also involved in ROS stress and redox control. Oxidative stress also induces the translocation of the AhR transcription factor to the ER and mitochondria (MIT), which increases ROS production. The antioxidation against ROS by the Nrf2 transcription factor helps to prevent cell damage during the initial phase; however, the excess of ROS causes apoptosis and other types of cellular death in infected host cells. The life cycle of IVs is summarized and the possible targets of drugs to treat IV infection are also indicated.

H5V1 virus [174]. In addition, cellular damage in the lungs suppresses TLR4 [174]. However, Garigliany et al. insisted that the effect of NAC is strain dependent and that this molecule lacks inhibitory activity against some IVs. NAC is effective against $\mathrm{A} / \mathrm{PR} / 8$ and $\mathrm{H} 5 \mathrm{~N} 1$, but not against murinized swine H1N1 IV [177]. The synergistic use of NAC and antiviral drugs as a combination therapy provides effective protection against IV infection in mice $[173,175]$.

\section{Glutathione}

The antiviral activity of GSH may be involved in inhibiting the synthesis of viral proteins [178]. A higher level of GSH might interfere with the formation of disulfide bonds, thus preventing the correct folding of viral hemagglutinin (HA), followed by the alteration of its transport and its insertion into host cell membranes [179]. Furthermore, a derivative of GSH, N-butanoyl glutathione (GSH-C4), which is a cell-permeable chemical compound [180], diminishes IV replication by maintaining the immature monomeric $\mathrm{HA}$ in the ER and inhibiting the targeting of mature membrane glycoproteins, which is achieved via an increase in GSH levels [180]. GSH-C4 affects the inflammatory response via NF-kB signaling and improves the Th1 response against IV in old mice [181, 182].

GSH inhibits the viral apoptosis induced by IVs and the production of IV particles. It also depresses the expression of viral matrix proteins, caspase cascades, and Fas induction [52]. Moreover, nutritional supplements that induce GSH may afford resistance to the major pathogenic processes of H5N1 [183]. Bakuchiol, a phenolic isoprenoid, activates the Nrf2 pathway and blocks IV infection, which suggests that bakuchiol has antiviral activity [28]. Overexpression of Nrf2 or the addition of sulforaphane and EGCG decreases the replication of, and protein synthesis in, IVs [54] (Fig. 2). Moreover, Nrf2 knockdown increases the entry and replication of IVs and enhances IV-induced pulmonary cell injury [54, 141]. Nrf2 is also a factor in the outcome of IV-infected mice after exposure to cigarette smoke [141]. Nrf2-deficient mice exhibit more severe bronchial 
Table 1 Drugs and small molecules against ROS that prevent infection with influenza viruses. [Against ROS]

\begin{tabular}{|c|c|c|}
\hline Thiol compounds and prodrugs & Effect on influenza virus infection & References \\
\hline N-acetyl-L-cysteine (NAC) & $\begin{array}{l}\text { - Reduction of the cell population at the G0/G1 } \\
\text { phase } \\
\text { - Reduction of pro-inflammatory molecule }\end{array}$ & $\begin{array}{l}\text { Geiler et al. } \\
\text { [174] } \\
\text { Ghezzi et al. } \\
\text { [175] } \\
\text { Wu et al. [197] } \\
\text { Zhang et al } \\
\text { [176] } \\
\text { Garigliany et al. } \\
\text { [177] }\end{array}$ \\
\hline Glutathione (GSH) & $\begin{array}{l}\text { - Affects viral mRNA export and decreases the } \\
\text { expression of late viral proteins } \\
\text { - Inhibition of caspase activation and Fas } \\
\text { upregulation }\end{array}$ & $\begin{array}{l}\text { Nencioni et al } \\
\text { [198] } \\
\text { Cai et al. [52] }\end{array}$ \\
\hline GSH-C4 & $\begin{array}{l}\text { - Inhibition of influenza virus HA maturation } \\
\text { - Inhibition of influenza virus replication and Th1 } \\
\text { immune cells induction }\end{array}$ & $\begin{array}{l}\text { Sgarbanti et al. } \\
{[180]} \\
\text { Amatore et al. } \\
{[44]}\end{array}$ \\
\hline PDTC (pyrrolidine dithiocarbamate) & $\begin{array}{l}\text { - Decrease in viral RNA synthesis } \\
\text { - Inhibition of apoptosis }\end{array}$ & $\begin{array}{l}\text { Uchide et al. } \\
\text { [199] } \\
\text { Qi et al. [200] }\end{array}$ \\
\hline Hydroxyl antioxidants & Effect on influenza virus infection & References \\
\hline $\begin{array}{l}\text { NDGA } \\
\text { (Nordihydroguaiaretic acid) }\end{array}$ & $\begin{array}{l}\text { - Inhibition of apoptotic DNA fragmentation and } \\
\text { virus proliferation }\end{array}$ & $\begin{array}{l}\text { Uchide et al. } \\
\text { [201] }\end{array}$ \\
\hline Thujaplicin & $\begin{array}{l}\text { - Inhibition of apoptosis, virus replication and } \\
\text { release from the infected cells }\end{array}$ & $\begin{array}{l}\text { Miyamoto et al. } \\
{[202]} \\
\text { Uchide et al } \\
\text { [203] }\end{array}$ \\
\hline $\begin{array}{l}\text { Resveratrol/ Vitisin A } \\
\text { (tetramer of resveratrol) }\end{array}$ & $\begin{array}{l}\text { - Inhibition of the nuclear-cytoplasmic } \\
\text { translocation of vRNP } \\
\text { - Downregulation of viral proteins } \\
\text { - Inhibition of protein kinase C activity } \\
\text { - Inhibition of virus-induced RANTES production, to } \\
\text { decrease of the virus-stimulated phosphorylation } \\
\text { of Akt and STAT1 }\end{array}$ & $\begin{array}{l}\text { Palamara et al. } \\
\text { [204] } \\
\text { Huang et al. } \\
\text { [205] } \\
\text { Uchide et al } \\
\text { [203] }\end{array}$ \\
\hline Ambroxol & $\begin{array}{l}\text { - Stimulation of the release of pulmonary } \\
\text { surfactants, mucus protease inhibitor, IgA, and IgG } \\
\text { - Suppression of the release of cytokines, TNF-a } \\
\text { IFN- } \gamma \text {, and interleukin-12 }\end{array}$ & $\begin{array}{l}\text { Yang et al. } \\
\text { [206] } \\
\text { Uchide et al. } \\
\text { [203] }\end{array}$ \\
\hline Ascorbic acid & $\begin{array}{l}\text { - Inhibition of the entry of viruses } \\
\text { - Increase in the production of IFN- } \alpha / \beta \text { at the initial } \\
\text { stage of infection } \\
\text { - Inhibition of excessive CORT synthesis }\end{array}$ & $\begin{array}{l}\text { Wang et al. } \\
{[207]} \\
\text { Kim et al. [208] } \\
\text { Cai et al. [209] } \\
\text { Kim et al. [210] }\end{array}$ \\
\hline Tert-buthylhydroquinone (tBHQ) & $\begin{array}{l}\text { - Inhibiting of ROS production and increase } \\
\text { antioxidation }\end{array}$ & $\begin{array}{l}\text { Antanasijevic } \\
\text { et al. [211, 212] }\end{array}$ \\
\hline Monoacetylcodine (MAC) + Curcumin & $\begin{array}{l}\text { - Inhibition NA activity } \\
\text { - Inhibition IAV infection better then curcumin only }\end{array}$ & $\begin{array}{l}\text { Richart et al. } \\
\text { [213] }\end{array}$ \\
\hline Curcumin + Resveratrol & $\begin{array}{l}\text { - Scavenging of } \mathrm{H} 2 \mathrm{O} 2, \mathrm{HON} \text {, and ROON } \\
\text { • Inhibition of TLR 2/4, p38MAPK, and NFkB }\end{array}$ & $\begin{array}{l}\text { Sharma et al. } \\
\text { [214] } \\
\text { Barzeger et al. } \\
\text { [215] } \\
\text { Dai et al. [216] }\end{array}$ \\
\hline Emodin (1,3,8-trihydroxy-6-methyl anthraquinone) & $\begin{array}{l}\text { - Inhibition of IA replication, IV pneumonia } \\
\text { - Inhibition of TLR 4, p38/JNK, and NFkB }\end{array}$ & Dai et al. [217] \\
\hline Oxymatrine (OMT); $\mathrm{C} 15 \mathrm{H} 24 \mathrm{~N} 2 \mathrm{O} 20$, imunosuppressive reagent & $\begin{array}{l}\text { - Antioxidant } \\
\text { - Suppression of inflammation and viral infections } \\
\text { - Hepatoprotective and immunosuppressive } \\
\text { - Inducer of TLR4, p38 MAPK, NFkB, and PI3KJAkT }\end{array}$ & Dai et al. [56] \\
\hline Aurantiamide acetate (E17) & - Strong anti-inflammatory and antiviral effects & $\begin{array}{l}\text { Zhou et al. } \\
\text { [218] }\end{array}$ \\
\hline
\end{tabular}


Table 1 Drugs and small molecules against ROS that prevent infection with influenza viruses. [Against ROS] (Continued)

\begin{tabular}{|c|c|c|}
\hline Thiol compounds and prodrugs & Effect on influenza virus infection & References \\
\hline 4-PBA (4-phenyl butyrate) & - Inhibitor of ER stress & $\begin{array}{l}\text { Jung et al. } \\
\text { [129] }\end{array}$ \\
\hline Kaempferol & $\begin{array}{l}\text { - Inhibition of TLR4/MyD88-mediated signaling of } \\
\text { NFkB and MAPK }\end{array}$ & $\begin{array}{l}\text { Zhang et al. } \\
{[57]}\end{array}$ \\
\hline Apocynin & $\begin{array}{l}\text { - Inhibitor of NOX2 } \\
\text { - Inhibition of ROS and IV-induced cytokine } \\
\text { production }\end{array}$ & Ye et al. [45] \\
\hline Flavonoids & Effect on influenza virus infection & References \\
\hline Dianthus (quercetin 3; isorhamnetin 3) & $\begin{array}{l}\text { - Binding to IV polymerase membrane } \\
\text { glycoproteins ROS inhibitor }\end{array}$ & Kim et al. [219] \\
\hline $\begin{array}{l}\text { Quercetin } \\
\text { Quercetin 3-glucoside }\end{array}$ & $\begin{array}{l}\text { - Protecting low-density lipoprotein against } \\
\text { oxidation } \\
\text { - Antithrombic, antivirus, and anti-inflammatory } \\
\text { effcets } \\
\text { - Supression of ROS }\end{array}$ & $\begin{array}{l}\text { Formica et al. } \\
\text { [220] } \\
\text { Nile et al. [221] }\end{array}$ \\
\hline Polyphenol & Effect on influenza virus infection & References \\
\hline Chlorogenic acid & $\begin{array}{l}\text { - Antivirus and antihypertension effects } \\
\text { - Protection of dopaminergic neurons against } \\
\text { neuroinflammation }\end{array}$ & $\begin{array}{l}\text { Zhao et al. } \\
\text { [222] } \\
\text { Shen et al. } \\
\text { [223] } \\
\text { Ding et al. } \\
\text { [224] }\end{array}$ \\
\hline Bakuchiol & - Activation of Nrf2 pathway & Shoji et al. [28] \\
\hline Chemicals & Effect on influenza virus infection & References \\
\hline $\begin{array}{l}\text { Poly (aniline-co-pyrrole) polymerized nanoregulators (PASomes) with mPEG- } \\
\text { b-pPhe (methoxy polyethylene glycol-block-polyphenylalanine copolymer) }\end{array}$ & $\begin{array}{l}\text { - Inhibition of ROS production } \\
\text { - Inhibition of viral replication and cell death }\end{array}$ & Kim et al. [225] \\
\hline $\begin{array}{l}\text { Cholesterol conjugated gp91 of NOX2 oxidase gp91 phox sequence linked } \\
\text { to the human immunodeficiency virus-tat peptide (Cgp91de-TAT) }\end{array}$ & $\begin{array}{l}\text { - Inhibitor of NOX2 oxidase } \\
\text { - Inhibitor of ROS and inflammation }\end{array}$ & To et al. [226] \\
\hline Ectonucleotide pyrophosphatase/phosphodiesterase 1 (ENPP-1) & $\begin{array}{l}\text { - Inhibition of HO-1 } \\
\text { • Inhibition of H9N2 proliferation }\end{array}$ & Qi et al. [227] \\
\hline Genes & Effect on influenza virus infection & References \\
\hline Bax Inhibitor-1 & $\begin{array}{l}\text { - Inhibiting ROS mdiated cell death and } \\
\text { augmented HO-1 } \\
\text { - H9N2-NS1 induced ROS and apoptosis }\end{array}$ & $\begin{array}{l}\text { Hosain et al. } \\
\text { [228] } \\
\text { Qi et al. [200] }\end{array}$ \\
\hline
\end{tabular}

inflammation, permeability damage in the lungs, mucus hypersecretion, and higher mortality rates after IV infection and cigarette smoke exposure than do wild-type mice [141]. Taken together, these results suggest that the Nrf2-mediated antioxidant pathway plays a critical role in suppressing IV-induced LI under oxidative conditions, such as cigarette smoke exposure [48, 141, 182-184].

\section{Other small molecules}

Many compounds that are traditionally regarded as antioxidants are really electrophiles, and their actions involve the activation of redox pathways through Nrf2 signaling, rather than the scavenging of ROS [185]. Isoprenoid phenols (e.g., baicalein and biochanin) prevent the replication of the highly pathogenic avian $\mathrm{H} 5 \mathrm{~N} 1$ virus by repressing ROS production [186]. EGCG and catechin exhibit an antiviral activity that involves antioxidation [187, 188]. Quercetin decreases the production of superoxide in alveolar macrophages during IV infection [88] and exerts an antiviral activity by inhibiting HA2 during IV infection [189]. A bioflavonoid isolated from Garcinia kola seeds (kolaviron) exhibits strong anti-IV activity via an antioxidative pathway [190].

\section{Nontargeted inhibition (NF-KB, p38 MAPK, and PI3K/AKT inhibitors)}

The effects of the dietary flavonoid kaempferol on H9N2-mediated acute LI included the repression of oxidative stress and inflammatory responses via the downregulation of NF- $\mathrm{KB}$ [57]. Kaempferol inhibits the NF- $\kappa B$ and MAPK pathways, leading to an increase in SOD activity, the attenuation of ROS levels, and H9N2induced acute LI [57]. Some ROS scavengers, such as polyphenols, may modulate the NF-kB and MAPK pathways and upregulate GSH biosynthesis through Nrf2 activation [154, 172, 190-194]. The immune-regulatory properties of NAC and IV-induced pneumonia are 
Table 2 Drugs and small molecules against influenza virus that prevent infection with influenza viruses. [Against Influenza viruses]

\begin{tabular}{|c|c|c|}
\hline Hydroxyl antioxidants & Effect on influenza virus infection & References \\
\hline Atorvastatin (Lipitor) & Inhibition of HMG-CoA reductase & Episcopio et al. [229] \\
\hline Clarithromycin (Biaxin) & $\begin{array}{l}\text { Inhibition of MCP-1 and MMP-9, } \\
\text { Increases of IL6 and IFNgamma }\end{array}$ & Takahashi et al. [230] \\
\hline Flavonoids & Effect on influenza virus infection & References \\
\hline 5,7,4'-Trihydroxy-8-methoxyflavone & Inhibition of virus fusion with endosome/lysosome membranes & Nagai et al. [231-235] \\
\hline Catechins & $\begin{array}{l}\text { Inhibition of } \mathrm{HA} \text { and NA activity } \\
\text { Inhibition of viral endonuclease activity }\end{array}$ & $\begin{array}{l}\text { Song et al. [188] } \\
\text { Kazuhara et al. [236] }\end{array}$ \\
\hline Quercetin 3-rhamnoside & Reduction of the cytopathic effect (CPE) & Choi et al. [237] \\
\hline Isoquercetin & Decrease in viral titers & Kim et al. [219] \\
\hline Oligonol (+NAC) & Inhibition of nuclear export of vRNP & Gangehei et al .[238] \\
\hline Viral enzymes and membrane proteins as targets & Effect on influenza virus infection & References \\
\hline \multirow[t]{4}{*}{ Amantadine } & Inhibitor of the matrix protein $\mathrm{M} 2$ & Pica and Palese [239] \\
\hline & $\begin{array}{l}\text { Selenium nanoparticles with amantadine } \\
\text { ROS-mediated AKT phosphorylation signal against H1N1 }\end{array}$ & Nabar et al. [240] \\
\hline & Selenium nanoparticles with ribavirin RNA polymerase inhibitor & $\begin{array}{l}\text { Lin et al. [241] } \\
\text { Li et al. [161] }\end{array}$ \\
\hline & Activation of the caspase-3 apoptotic pathway against H1N1 & $\begin{array}{l}\text { Li et al. [161] } \\
\text { Lin el al [241]. }\end{array}$ \\
\hline Prion & $\begin{array}{l}\text { Protects mice from lethal infection with IAV } \\
\text { Reduce the ROS in infected lung }\end{array}$ & Chida et al. [242] \\
\hline NS1 & H9N2-NS1 induced ROS and apoptosis & Qi et al. [200] \\
\hline Oseltamivir and zanamivir & Inhibitor of neuraminidase (NA) & Kode et al. [243] \\
\hline Laninamivir & Inhibitor of $\mathrm{HA}$ & Tomozawa et al. [244] \\
\hline Peramivir & Inhibitor of HA & Scott et al. [245] \\
\hline Rimantadine & Inhibitor of M2 ion channel & Alves Galvão et al. [246] \\
\hline NMS-873 & $\begin{array}{l}\text { Inhibitor of p97 (AAA+ ATPase, VCP) } \\
\text { Oseltamivir resistant strain specific }\end{array}$ & Zhang et al. [247] \\
\hline Baloxavir marboxil & Cap-dependent endonuclease inhibitor & O'Hanlon et al. [248] \\
\hline $\begin{array}{l}\text { 1,3-dihydorxy-6-benzo[C] chromone } \\
\text { D715-2441 + zanamivir }\end{array}$ & $\begin{array}{l}\text { PB2 Inhibitor } \\
\text { Binding to PBcap }\end{array}$ & Liu et al. [249] \\
\hline Salinomycin + oseltamivir (OSV-P) & $\begin{array}{l}\text { M2 channel blocker } \\
\text { Inhibition of HA }\end{array}$ & Jang et al., [250] \\
\hline 10e (Am2-S31N blocker) & Proton channel blocker and M2 blocker & Hu et al. [251] \\
\hline Favipiravir & PB1 inhibitor & Goldhill et al. [252] \\
\hline $\begin{array}{l}\text { Triple combination of } \\
\text { Zanamivir + Clarithromycin + Flufenamic acid (FFA) }\end{array}$ & Inhibitor of $\mathrm{HA}$ & Lee et al. [253] \\
\hline Others & Effect on influenza virus infection & References \\
\hline Single-walled carbon nanotubes (SWCNTs) & Increasing of H1N1 viral titer & $\begin{array}{l}\text { Chen et al. [254] } \\
\text { Sanpui et al. [255] }\end{array}$ \\
\hline Umifenovir & Interact with $\mathrm{HA}$ to inhibit $\mathrm{HA}$ & Chida et al. [242] \\
\hline
\end{tabular}

related to the inhibition of the p38 MAPK pathway [195]. Thus, NF- $\mathrm{kB}$ activation and the p38 MAPK, pI3K/ $\mathrm{AKT}$, and PKC/PKR pathways may serve as biomarkers of oxidative stress [192, 196]. M2 ion channel inhibitors, such as oseltamivir/amantadine (AM)-modified selenium nanoparticles (SeNPs; Se@AM), inhibit the H1N1induced apoptosis of host cells through ROS-mediated AKT signaling pathways [161].

\section{Conclusions}

The pathophysiology of IV infection is related, at least in part, with the imbalance between oxidation and antioxidation systems, as well as with the state of AhR activation (Fig. 3). In this review, we presented several examples of the effect of the IV-host interactions on the intracellular redox and ROS states. Based on this knowledge, several potential therapeutics for the treatment or prevention of 
IV infection are presented (Tables $\mathbf{1}$ and 2). Heaton et al. [256] reported a CRISPR activation screening that aimed to identify a pan-avian IV-inhibitor host factor; those authors isolated the glycosyltransferase B4GALNT2, which can modify glycans containing $\alpha$-2,3-linked sialic acids. However, most of these proposed therapeutic strategies require validation using animal models of IV infection and human clinical trials. Although many studies have uncovered the multifaceted roles of the cellular redox system and of ROS activity in IV-infection-induced lung inflammation and injury, several questions remain unanswered that are important for illustrating the precise IV-host interaction and that await further investigation. For example, both oxidative stress and virus replication result in chromatin remodeling, which largely affects gene expression, including that of Nrf2- and AhR-regulated genes, and determines the outcome of the virus-host interaction. Understanding the precise crosstalk between multiple chromatin modifiers, such as histone acetyltransferases/ deacetylases and methyltransferases/demethylases, and the transcription factors Nrf2 and AhR upon IV infection is required to predict the consequences of viral infection accurately. Accordingly, a more specific and effective intervention for IV infection may be developed by targeting either ROS homeostasis or chromatin modifiers [257, 258]. In conclusion, this review presents the notion that, in addition to viral components, the therapeutic treatment of IV infection may be achieved by targeting virusinduced ROS and redox-associated cellular responses, which may suppress IV propagation and reduce adverse inflammation in the host.

\footnotetext{
Abbreviations

AhR: Aryl hydrocarbon receptor; AIM: Absence in melanoma; ALR: AIM2-like receptor; ALI: Acute lung injury; ARE: Antioxidant response element; BBR: Berberine; CAT: Catalase; CO: Carbon monoxide; CSN: Central nervous system; CYP: Cytochrome p450; DAMP: Danger-associated molecular pattern; DC: Dendric cells; DRP1: Dynamin-related protein 1; Duox: Dual oxidase; EGCG: Epigallocatechin gallate; ER: Endoplasmic reticulum; GABA: Gammaaminobutyric acid; GPx: Glutathione peroxidase; FAK: Focal adhesion kinase; Fe-S: Iron-sulfur; GR: Glutaredoxin; GSH: Glutathione; GSH-C4: N-butanoyl glutathione; GSSG: Glutathione disulfide; HA: Hemagglutinin; HO-1: Heme oxygenase-1; $\mathrm{H}_{2} \mathrm{O}_{2}$ : Hydrogen peroxide; 8-OHdG: 8'-hydroxy-2'deoxyguanosine; $\mathrm{OH}$ : Hydroxyl radicals; $\mathrm{H}_{2} \mathrm{~S}$ : Hydrogen sulfide; $\mathrm{HS}$ : Sulfanyl radical; IAV: Influenza A virus; IDO: Indoleamine-2,3-dooxygenase;

IFN: Interferon; iNOS: Inducible nitric oxide synthetase; IRE1: Inositol-requiring enzyme 1; IV: Influenza virus; Keap1: Kelch-like ECH-associated protein 1; LI: Lung injury; MAPK: Mitogen activated protein kinase; MDA5: Melanomaassociated differentiation gene 5; MDCK: Madin-Darby canine kidney cells; MIT: Mitochondria; MMP: Matrix metalloproteinase; NAC: N-acetyl L-cysteine; NADPH: Nicotine adenine dinucleotide phosphate; NFkB: Nuclear factor kappa B; NLRP3: NOD-like receptor pyrin domain-containing-3 (NLRP3); NO: Nitric oxide; NOD: Nucleotide-binding and oligomerization domain; NOX: Nicotine adenine dinucleotide phosphate oxidase; NP: Nucleoprotein; Nrf2: Nuclear factor E2-related factor 2; NQO1: NADPH quinone oxidoreductase $1 ; \mathrm{O}_{2}^{-}$: Superoxide anion; PAMP: Pathogen-associated molecular pattern; PAN: Porcine alveolar macrophage; PB1: Polymerase basic protein 1; PB2: Polymerase basic protein 2; PDIA 3: Protein disulfide isomerase 3; Prdx: Peroxiredoxin; Prr: Pattern-recognition receptor; RIG: Retinoic acid-inducible gene; SOD: Superoxide dismutase; RNS: Reactive nitrogen species; ROS: Reactive oxygen species; SA: Sialic acid;
}

SFN: Sulforaphane; SIV: Swine IV; TCA: Tricarboxylic acid; TCDD: 2,3,7,8Tetrachlorodibenzodioxin; TLR: Toll-like receptor; TNFa: Tumor necrosis factor a; TXNRD: Thioredoxin reductase; vRNP: viral ribonucleoprotein; XBP1: X-box binding protein $1 ; \mathrm{XO}$ : Xanthine oxidase

\section{Acknowledgments}

We thank the researchers in the laboratories of Drs. Kyosuke Nagata and Kohsuke Kato from Tsukuba University in Japan for useful discussions about the editing of this manuscript.

\section{Authors' contributions}

$\mathrm{KKC}, \mathrm{MM}, \mathrm{KW}, \mathrm{KKK}, \mathrm{YCL}, \mathrm{SS}, \mathrm{KKY}$, and CSL participated in the study design and wrote the draft. KKC, KW, MM, KKK, JBP, and CCK collected the documentation materials. KKC, MM, KW, JBP, CCK, SS, CSL, and KKY participated in the study design and helped revise the draft. All authors read and approved the manuscript.

\section{Funding}

This work was supported partially by grants from the Ministry of Science and Technology (MOST 106-2320-B-037-001-MY3, MOST 107-2314-B-037-085, MOST 107-2320-B-037-026, and MOST 108-2320-B-037-005), by the National Health Research Institutes (NHRI-EX108-10720SI); and by Kaohsiung Medical University grants (KMU-TC108A02) and Kaohsiung Medical University Hospital grant (SA10803C).

\section{Availability of data and materials}

Not applicable.

Ethics approval and consent to participate

Not applicable.

\section{Consent for publication}

Not applicable

\section{Competing interests}

The authors declare that they have no competing interests.

\section{Author details}

${ }^{1}$ School of Dentistry, Kaohsiung Medical University, Kaohsiung 807, Taiwan. ${ }^{2}$ Department of Densitory, Kaohisung University Hospital, Kaohisung 807, Taiwan. ${ }^{3}$ Waseda Research Institute for Science and Engineering, Waseca University, Shinjuku, Tokyo 162-8480, Japan. ${ }^{4}$ Graduate Institute of Medicine, Kaohsiung Medical University, 100 Shih-Chuan 1st Rd., San-Ming District, Kaohsiung 80807, Taiwan. ${ }^{5}$ Regenerative Medicine and Cell Therapy Research Center, Kaohsiung Medical University, Kaohsiung 807, Taiwan. ${ }^{6}$ Department Surgery, Kaohsiung Medical University Hospital, Kaohsiung 807, Taiwan. ${ }^{7}$ Saito Laboratory of Cell Technology Institute, Yalta, Tochigi 329-1471, Japan. ${ }^{8}$ Department of Biological Sciences, National Sun Yat-sen University, Kaohsiung 80424, Taiwan. ${ }^{9}$ Cell Therapy and Research Center, Kaohsiung Medical University Hospital, Kaohsiung 807, Taiwan.

Received: 24 February 2020 Accepted: 1 July 2020

Published online: 20 July 2020

\section{References}

1. Kuiken T, Taubenberger JK. Pathology of human influenza revisited. Vaccine. 2008;26(Suppl 4):D59-66

2. Furuta Y, Gowen BB, Takahashi K, Shiraki K, Smee DF, Barnard DL. Favipiravir (T-705), a novel viral RNA polymerase inhibitor. Antivir Res. 2013:100:446-54

3. Das K. Antivirals targeting influenza A virus. J Med Chem. 2012;55:6263-77.

4. Shie JJ, Fang JM. Development of effective anti-influenza drugs: congeners and conjugates - a review. J Biomed Sci. 2019;26:84.

5. Zachary, K.C. Pharmacology of antiviral drugs for influenza. Martin S Hirsch, M.S.E., Allyson Bloom, Ed. Wolters Kluwer: UpToDate, 2020.

6. Massari S, Goracci L, Desantis J, Tabarrini O. Polymerase Acidic Protein-Basic Protein 1 (PA-PB1) Protein-Protein Interaction as a Target for NextGeneration Anti-influenza Therapeutics. J Med Chem. 2016:59:7699-718.

7. Stevaert A, Naesens L. The Influenza Virus Polymerase Complex: An Update on Its Structure, Functions, and Significance for Antiviral Drug Design. Med Res Rev. 2016:36:1127-73.

8. Heo YA. Baloxavir: First Global Approval. Drugs. 2018;78:693-7. 
9. Rasmussen SA, Jamieson DJ, Bresee JS. Pandemic influenza and pregnant women. Emerg Infect Dis. 2008;14:95-100.

10. To EE, Erlich JR, Liong F, Luong R, Liong S, Esaq F, Oseghale O, Anthony D, McQualter J, Bozinovski S, et al. Mitochondrial Reactive Oxygen Species Contribute to Pathological Inflammation During Influenza A Virus Infection in Mice. Antioxid Redox Signal. 2020;32:929-42.

11. Imai Y, Kuba K, Neely GG, Yaghubian-Malhami R, Perkmann T, van Loo G, Ermolaeva M, Veldhuizen $\mathrm{R}$, Leung $\mathrm{YH}$, Wang $\mathrm{H}$, et al. Identification of oxidative stress and Toll-like receptor 4 signaling as a key pathway of acute lung injury. Cell. 2008;133:235-49.

12. Akaike T, Okamoto S, Sawa T, Yoshitake J, Tamura F, Ichimori K, Miyazaki K, Sasamoto K, Maeda H. 8-nitroguanosine formation in viral pneumonia and its implication for pathogenesis. Proc Natl Acad Sci U S A. 2003;100:685-90.

13. Vlahos R, Stambas J, Bozinovski S, Broughton BR, Drummond GR, Selemidis S. Inhibition of Nox2 oxidase activity ameliorates influenza A virus-induced lung inflammation. PLoS Pathog. 2011;7:e1001271.

14. Murphy MP. How mitochondria produce reactive oxygen species. Biochem J. 2009:417:1-13.

15. Cadenas E. Mitochondrial free radical production and cell signaling. Mol Aspects Med. 2004:25:17-26.

16. Di Meo S, Reed TT, Venditti P, Victor VM. Role of ROS and RNS Sources in Physiological and Pathological Conditions. Oxid Med Cell Longev. 2016; 2016:1245049.

17. Griendling KK, Sorescu D, Ushio-Fukai M. NAD(P)H oxidase: role in cardiovascular biology and disease. Circ Res. 2000;86:494-501.

18. To EE, Vlahos R, Luong R, Halls ML, Reading PC, King PT, Chan C, Drummond GR, Sobey CG, Broughton BRS, et al. Endosomal NOX2 oxidase exacerbates virus pathogenicity and is a target for antiviral therapy. Nat Commun. 2017;8:69.

19. Zangar RC, Davydov DR, Verma S. Mechanisms that regulate production of reactive oxygen species by cytochrome P450. Toxicol Appl Pharmacol. 2004; 199:316-31.

20. Agostinelli E, Tempera G, Viceconte N, Saccoccio S, Battaglia V, Grancara S, Toninello A, Stevanato R. Potential anticancer application of polyamine oxidation products formed by amine oxidase: a new therapeutic approach. Amino Acids. 2010;38:353-68.

21. Paloczi J, Varga ZV, Hasko G, Pacher P. Neuroprotection in Oxidative StressRelated Neurodegenerative Diseases: Role of Endocannabinoid System Modulation. Antioxid Redox Signal. 2018;29:75-108.

22. Fujii S, Akaike T. Redox Signaling by 8-nitro-cyclic guanosine monophosphate: nitric oxide- and reactive oxygen species-derived electrophilic messenger. Antioxid Redox Signal. 2013;19:1236-46.

23. Sawa T, Akaike T, Ichimori K, Akuta T, Kaneko K, Nakayama H, Stuehr DJ, Maeda H. Superoxide generation mediated by 8-nitroguanosine, a highly redox-active nucleic acid derivative. Biochem Biophys Res Commun. 2003; 311:300-6.

24. Ng MP, Lee JC, Loke WM, Yeo LL, Quek AM, Lim EC, Halliwell B, Seet RC. Does influenza A infection increase oxidative damage? Antioxid Redox Signal. 2014;21:1025-31.

25. Masella R, Di Benedetto R, Vari R, Filesi C, Giovannini C. Novel mechanisms of natural antioxidant compounds in biological systems: involvement of glutathione and glutathione-related enzymes. J Nutr Biochem. 2005;16:577-86.

26. Reshi ML, Su YC, Hong JR. RNA Viruses: ROS-Mediated Cell Death. Int J Cell biol. 2014;2014:467452.

27. Winterbourn CC, Hampton MB. Thiol chemistry and specificity in redox signaling. Free Radic Biol Med. 2008:45:549-61.

28. Shoji M, Arakaki Y, Esumi T, Kohnomi S, Yamamoto C, Suzuki Y, Takahashi E, Konishi S, Kido H, Kuzuhara T. Bakuchiol Is a Phenolic Isoprenoid with Novel Enantiomer-selective Anti-influenza A Virus Activity Involving Nrf2 Activation. J Biol Chem. 2015;290:28001-17.

29. Krajka-Kuzniak V, Paluszczak J, Baer-Dubowska W. The Nrf2-ARE signaling pathway: An update on its regulation and possible role in cancer prevention and treatment. Pharmacol Rep. 2017;69:393-402.

30. Murray IA, Patterson AD, Perdew GH. Aryl hydrocarbon receptor ligands in cancer: friend and foe. Nat Rev Cancer. 2014;14:801-14.

31. Teske S, Bohn AA, Hogaboam JP, Lawrence BP. Aryl hydrocarbon receptor targets pathways extrinsic to bone marrow cells to enhance neutrophil recruitment during influenza virus infection. Toxicol Sci. 2008; 102:89-99.
32. Neff-LaFord H, Teske S, Bushnell TP, Lawrence BP. Aryl hydrocarbon receptor activation during influenza virus infection unveils a novel pathway of IFNgamma production by phagocytic cells. J Immunol. 2007;179:247-55.

33. Wheeler JL, Martin KC, Lawrence BP. Novel cellular targets of AhR underlie alterations in neutrophilic inflammation and inducible nitric oxide synthase expression during influenza virus infection. J Immunol. 2013;190:659-68.

34. Wright PF, N. G, Kawaoka Y. Orthomyxoviruses. In Fields Virology, Knipe DM, H.P., Ed. LIPPINCOTT WILLIAMS \& WILKINS, a WOLTERS KLUWER BUSINESS: Philadelphia, PA 19106 USA, 2007; pp. 1691-1740.

35. Taubenberger JK, Morens DM. The pathology of influenza virus infections. Annu Rev Pathol. 2008:3:499-522.

36. de Jong MD, Simmons CP, Thanh TT, Hien VM, Smith GJ, Chau TN, Hoang DM, Chau NV, Khanh TH, Dong VC, et al. Fatal outcome of human influenza A (H5N1) is associated with high viral load and hypercytokinemia. Nat Med. 2006;12:1203-7.

37. Zamarin D, Garcia-Sastre A, Xiao X, Wang R, Palese P. Influenza virus PB1-F2 protein induces cell death through mitochondrial ANT3 and VDAC1. PLOS Pathog. 2005;1:e4.

38. Conenello GM, Zamarin D, Perrone LA, Tumpey T, Palese P. A single mutation in the PB1-F2 of H5N1 (HK/97) and 1918 influenza A viruses contributes to increased virulence. PLoS Pathog. 2007:3:1414-21.

39. Mazur I, Anhlan D, Mitzner D, Wixler L, Schubert U, Ludwig S. The proapoptotic influenza $\mathrm{A}$ virus protein $\mathrm{PB} 1-\mathrm{F} 2$ regulates viral polymerase activity by interaction with the PB1 protein. Cell Microbiol. 2008;10:1140-52.

40. Tumpey TM, Maines TR, Van Hoeven N, Glaser L, Solorzano A, Pappas C, Cox NJ, Swayne DE, Palese P, Katz JM, et al. A two-amino acid change in the hemagglutinin of the 1918 influenza virus abolishes transmission. Science. 2007;315:655-9.

41. van Riel D, Munster VJ, de Wit E, Rimmelzwaan GF, Fouchier RA, Osterhaus AD, Kuiken T. Human and avian influenza viruses target different cells in the lower respiratory tract of humans and other mammals. Am J Pathol. 2007; 171:1215-23.

42. Lim JY, Oh E, Kim Y, Jung WW, Kim HS, Lee J, Sul D. Enhanced oxidative damage to DNA, lipids, and proteins and levels of some antioxidant enzymes, cytokines, and heat shock proteins in patients infected with influenza H1N1 virus. Acta Virol. 2014;58:253-60.

43. Nin N, Sanchez-Rodriguez C, Ver LS, Cardinal P, Ferruelo A, Soto L, Deicas A, Campos N, Rocha O, Ceraso DH, et al. Lung histopathological findings in fatal pandemic influenza A (H1N1). Med Intensiva. 2012;36:24-31.

44. Amatore D, Sgarbanti R, Aquilano K, Baldelli S, Limongi D, Civitelli L, Nencioni L, Garaci E, Ciriolo MR, Palamara AT. Influenza virus replication in lung epithelial cells depends on redox-sensitive pathways activated by NOX4-derived ROS. Cell Microbiol. 2015;17:131-45.

45. Ye $\mathrm{S}$, Lowther $\mathrm{S}$, Stambas J. Inhibition of reactive oxygen species production ameliorates inflammation induced by influenza A viruses via upregulation of SOCS1 and SOCS3. J Virol. 2015;89:2672-83.

46. Khomich OA, Kochetkov SN, Bartosch B, Ivanov AV. Redox Biology of Respiratory Viral Infections. Viruses. 2018;10.

47. Laghlali G, Lawlor KE, Tate MD. Die Another Way: Interplay between Influenza A Virus. Inflamm Cell Death Viruses. 2020;12:401.

48. Sgarbanti R, Amatore D, Celestino I, Marcocci ME, Fraternale A, Ciriolo MR, Magnani M, Saladino R, Garaci E, Palamara AT, et al. Intracellular redox state as target for anti-influenza therapy: are antioxidants always effective? Curr Top Med Chem. 2014;14:2529-41.

49. Lee C. Therapeutic Modulation of Virus-Induced Oxidative Stress via the Nrf2-Dependent Antioxidative Pathway. Oxid Med Cell Longev. 2018;2018: 6208067.

50. Kirkpatrick $C T$, Wang $Y$, Leiva Juarez MM, Shivshankar $P$, Pantaleon Garcia J, Plumer AK, Kulkarni W, Ware HH, Gulraiz F, Chavez Cavasos MA, et al. Inducible Lung Epithelial Resistance Requires Multisource Reactive Oxygen Species Generation To Protect against Viral Infections. mBio. 2018;9:e00696-00618.

51. Oda T, Akaike T, Hamamoto T, Suzuki F, Hirano T, Maeda H. Oxygen radicals in influenza-induced pathogenesis and treatment with pyran polymerconjugated SOD. Science. 1989;244:974-6.

52. Cai J, Chen Y, Seth S, Furukawa S, Compans RW, Jones DP. Inhibition of influenza infection by glutathione. Free Radic Biol Med. 2003;34:928-36.

53. Lin X, Wang R, Zou W, Sun X, Liu X, Zhao L, Wang S, Jin M. The Influenza Virus H5N1 Infection Can Induce ROS Production for Viral Replication and Host Cell Death in A549 Cells Modulated by Human Cu/Zn Superoxide Dismutase (SOD1) Overexpression. Viruses. 2016;8:13. 
54. Kesic MJ, Simmons SO, Bauer R, Jaspers I. Nrf2 expression modifies influenza A entry and replication in nasal epithelial cells. Free Radic Biol Med. 2011;51: 444-53

55. Checconi P, Salzano S, Bowler L, Mullen L, Mengozzi M, Hanschmann EM, Lillig CH, Sgarbanti R, Panella S, Nencioni L, et al. Redox proteomics of the inflammatory secretome identifies a common set of redoxins and other glutathionylated proteins released in inflammation, influenza virus infection and oxidative stress. PloS One. 2015;10:e0127086.

56. Dai JP, Wang QW, Su Y, Gu LM, Deng HX, Chen XX, Li WZ, Li KS. Oxymatrine Inhibits Influenza A Virus Replication and Inflammation via TLR4, p38 MAPK and NF-kappaB Pathways. Int J Mol Sci. 2018;19:965.

57. Zhang R, Ai X, Duan Y, Xue M, He W, Wang C, Xu T, Xu M, Liu B, Li C, et al. Kaempferol ameliorates H9N2 swine influenza virus-induced acute lung injury by inactivation of TLR4/MyD88-mediated NF-kappaB and MAPK signaling pathways. Biomed Pharmacother. 2017;89:660-72.

58. Ma Q, Kinneer K, Bi Y, Chan JY, Kan YW. Induction of murine NAD(P)H: quinone oxidoreductase by 2,3,7,8-tetrachlorodibenzo-p-dioxin requires the CNC (cap 'n' collar) basic leucine zipper transcription factor Nrf2 (nuclear factor erythroid 2-related factor 2): cross-interaction between AhR (aryl hydrocarbon receptor) and Nrf2 signal transduction. Biochem J. 2004;377: 205-13.

59. Rushmore $\mathrm{TH}$, Morton MR, Pickett CB. The antioxidant responsive element. Activation by oxidative stress and identification of the DNA consensus sequence required for functional activity. J Biol Chem. 1991; 266:11632-9.

60. Wheeler JL, Martin KC, Resseguie E, Lawrence BP. Differential consequences of two distinct AhR ligands on innate and adaptive immune responses to influenza A virus. Toxicol Sci. 2014;137:324-34

61. Yeager RL, Reisman SA, Aleksunes LM, Klaassen CD. Introducing the "TCDDinducible AhR-Nrf2 gene battery". Toxicol Sci. 2009;111:238-46.

62. Wang L, He X, Szklarz GD, Bi Y, Rojanasakul Y, Ma Q. The aryl hydrocarbon receptor interacts with nuclear factor erythroid 2-related factor 2 to mediate induction of $\mathrm{NAD}(\mathrm{P}) \mathrm{H}$ :quinoneoxidoreductase 1 by 2,3,7,8tetrachlorodibenzo-p-dioxin. Arch Biochem Biophys. 2013:537:31-8.

63. Jin GB, Moore AJ, Head JL, Neumiller JJ, Lawrence BP. Aryl hydrocarbon receptor activation reduces dendritic cell function during influenza virus infection. Toxicol Sci. 2010;116:514-22.

64. Head $J$, Lawrence BP. The aryl hydrocarbon receptor is a modulator of anti-viral immunity. Biochem Pharmacol. 2009;77:642-53.

65. Sies $\mathrm{H}$, Jones DP. Reactive oxygen species (ROS) as pleiotropic physiological signalling agents. Nat Rev Mol Cell Biol. 2020. https://doi.org/10.1038/ s41580-020-0230-3.

66. Roma Patel LR, Peng J, Chilian WM. Reactive oxygen species: the good and the bad. Intech Open. 2017. https://doi.org/10.5772/intechopen.71547.

67. Burggraaf S, Bingham J, Payne J, Kimpton WG, Lowenthal JW, Bean AG. Increased inducible nitric oxide synthase expression in organs is associated with a higher severity of H5N1 influenza virus infection. PloS One. 2011;6: e14561.

68. Zablockiene B, Kacergius T, Ambrozaitis A, Zurauskas E, Bratchikov M, Jurgauskiene L, Zablockis R, Gravenstein S. Zanamivir Diminishes Lung Damage in Influenza A Virus-infected Mice by Inhibiting Nitric Oxide Production. In Vivo. 2018;32:473-8.

69. Kamal RP, Alymova IV, York IA. Evolution and Virulence of Influenza A Virus Protein PB1-F2. Int J Mol Sci. 2017;19:96.

70. Shin N, Pyo CW, Jung Kl, Choi SY. Influenza A virus PB1-F2 is involved in regulation of cellular redox state in alveolar epithelial cells. Biochem Biophys Res Commun. 2015;459:699-705.

71. Pinar A, Dowling JK, Bitto NJ, Robertson AA, Latz E, Stewart CR, Drummond GR, Cooper MA, McAuley JL, Tate MD, et al. PB1-F2 Peptide Derived from Avian Influenza A Virus H7N9 Induces Inflammation via Activation of the NLRP3 Inflammasome. J Biol Chem. 2017;292:826-36.

72. Panday A, Sahoo MK, Osorio D, Batra S. NADPH oxidases: an overview from structure to innate immunity-associated pathologies. Cell Mol Immunol. 2015;12:5-23.

73. Mittal M, Roth M, Konig P, Hofmann S, Dony E, Goyal P, Selbitz AC, Schermuly RT, Ghofrani HA, Kwapiszewska G, et al. Hypoxia-dependent regulation of nonphagocytic NADPH oxidase subunit NOX4 in the pulmonary vasculature. Circ Res. 2007;101:258-67.

74. Ghatak S, Hascall VC, Markwald RR, Feghali-Bostwick C, Artlett CM, Gooz M, Bogatkevich GS, Atanelishvili I, Silver RM, Wood J, et al. Transforming growth factor beta1 (TGFbeta1)-induced CD44V6-NOX4 signaling in pathogenesis of idiopathic pulmonary fibrosis. J Biol Chem. 2017;292:10490519.

75. Bedard K, Krause KH. The NOX family of ROS-generating NADPH oxidases: physiology and pathophysiology. Physiol Rev. 2007;87:245-313.

76. Basuroy S, Tcheranova D, Bhattacharya S, Leffler CW, Parfenova H. Nox4 NADPH oxidase-derived reactive oxygen species, via endogenous carbon monoxide, promote survival of brain endothelial cells during TNF-alphainduced apoptosis. American journal of physiology. Cell Physiol. 2011;300: C256-65.

77. Selemidis S, Seow HJ, Broughton BR, Vinh A, Bozinovski S, Sobey CG, Drummond GR, Vlahos R. Nox1 oxidase suppresses influenza a virus-induced lung inflammation and oxidative stress. PloS One. 2013;8:e60792.

78. Hofstetter AR, De La Cruz JA, Cao W, Patel J, Belser JA, McCoy J, Liepkalns JS, Amoah S, Cheng G, Ranjan P, et al. NADPH Oxidase 1 Is Associated with Altered Host Survival and T Cell Phenotypes after Influenza A Virus Infection in Mice. PloS One. 2016;11:e0149864.

79. Strengert M, Jennings R, Davanture S, Hayes P, Gabriel G, Knaus UG. Mucosal reactive oxygen species are required for antiviral response: role of Duox in influenza a virus infection. Antioxid Redox Signal. 2014;20: 2695-709.

80. Hong SN, Kim JY, Kim H, Kim DY, Won TB, Han DH, Rhee CS, Kim HJ. Duox2 is required for the transcription of pattern recognition receptors in acute viral lung infection: An interferon-independent regulatory mechanism. Antiviral Res. 2016;134:1-5.

81. Kim HJ, Kim CH, Kim MJ, Ryu JH, Seong SY, Kim S, Lim SJ, Holtzman MJ, Yoon $\mathrm{JH}$. The Induction of Pattern-Recognition Receptor Expression against Influenza A Virus through Duox2-Derived Reactive Oxygen Species in Nasal Mucosa. Am J Respir Cell Mol Biol. 2015;53:525-35.

82. Daiber A, Di Lisa F, Oelze M, Kroller-Schon S, Steven S, Schulz E, Munzel T. Crosstalk of mitochondria with NADPH oxidase via reactive oxygen and nitrogen species signalling and its role for vascular function. Br J Pharmacol. 2017;174:1670-89.

83. Atkin-Smith GK, Duan M, Chen W, Poon IKH. The induction and consequences of Influenza A virus-induced cell death. Cell Death Dis. 2018; 9:1002.

84. Zhang R, Chi X, Wang S, Qi B, Yu X, Chen JL. The regulation of autophagy by influenza A virus. BioMed Res Int. 2014;2014:498083.

85. Biondo $C$, Lentini $G$, Beninati $C$, Teti $G$. The dual role of innate immunity during influenza. Biomed J. 2019;42:8-18.

86. Herold S, Becker C, Ridge KM, Budinger GR. Influenza virus-induced lung injury: pathogenesis and implications for treatment. Eur respir J. 2015;45: 1463-78.

87. Li N, Parrish M, Chan TK, Yin L, Rai P, Yoshiyuki Y, Abolhassani N, Tan KB, Kiraly $\mathrm{O}$, Chow VT, et al. Influenza infection induces host DNA damage and dynamic DNA damage responses during tissue regeneration. Cell Mol Life Sci. 2015;72:2973-88

88. Kumar P, Sharma S, Khanna M, Raj HG. Effect of Quercetin on lipid peroxidation and changes in lung morphology in experimental influenza virus infection. Int J Exp Pathol. 2003:84:127-33.

89. Buffinton GD, Christen S, Peterhans E, Stocker R. Oxidative stress in lungs of mice infected with influenza A virus. Free Radicl Res commun. 1992;16:99-110.

90. He G, Dong C, Luan Z, McAllan BM, Xu T, Zhao L, Qiao J. Oxygen free radical involvement in acute lung injury induced by $\mathrm{H} 5 \mathrm{~N} 1$ virus in mice. Influenza Other respi Viruses. 2013;7:945-53.

91. Vlahos R, Stambas J, Selemidis S. Suppressing production of reactive oxygen species (ROS) for influenza A virus therapy. Trends Pharmacol sci. 2012;33:3-8

92. Maurizi CP. Influenza caused epidemic encephalitis (encephalitis lethargica): the circumstantial evidence and a challenge to the nonbelievers. Med Hypotheses. 2010;74:798-801.

93. Toovey S. Influenza-associated central nervous system dysfunction: a literature review. Travel Med Infect Dis. 2008;6:114-24.

94. Ng YP, Lee SM, Cheung TK, Nicholls JM, Peiris JS, Ip NY. Avian influenza H5N1 virus induces cytopathy and proinflammatory cytokine responses in human astrocytic and neuronal cell lines. Neuroscience. 2010;168: 613-23

95. Wang G, Zhang J, Li W, Xin G, Su Y, Gao Y, Zhang H, Lin G, Jiao X, Li K. Apoptosis and proinflammatory cytokine responses of primary mouse microglia and astrocytes induced by human $\mathrm{H} 1 \mathrm{~N} 1$ and avian $\mathrm{H} 5 \mathrm{~N} 1$ influenza viruses. Cell Mol Immunol. 2008;5:113-20. 
96. Lin X, Wang R, Zhang J, Sun X, Zou Z, Wang S, Jin M. Insights into Human Astrocyte Response to H5N1 Infection by Microarray Analysis. Viruses. 2015, 7:2618-40.

97. Siegers JY, van de Bildt MWG, Lin Z, Leijten LM, Lavrijssen RAM, Bestebroer T, Spronken MIJ, De Zeeuw Cl, Gao Z, Schrauwen EJA, et al. Viral Factors Important for Efficient Replication of Influenza A Viruses in Cells of the Central Nervous System. J Virol. 2019;93:e02273-02218.

98. Lee N, Wong CK, Hui DS, Lee SK, Wong RY, Ngai KL, Chan MC, Chu YJ, Ho AW, Lui GC, et al. Role of human Toll-like receptors in naturally occurring influenza A infections. Influenza Other Respi Viruses. 2013;7:666-75.

99. Liu, Y.; Chen, H.; Sun, Y.; Chen, F. Antiviral role of Toll-like receptors and cytokines against the new 2009 H1N1 virus infection. Mol Biol Rep 2012, 39, 1163-1172.

100. Pan HY, Yano M, Kido H. Effects of inhibitors of Toll-like receptors, proteaseactivated receptor-2 signalings and trypsin on influenza A virus replication and upregulation of cellular factors in cardiomyocytes. J Med Invest. 2011; 58:19-28.

101. Song BM, Kang YM, Kim HS, Seo SH. Induction of inflammatory cytokines and toll-like receptors in human normal respiratory epithelial cells infected with seasonal H1N1, 2009 pandemic H1N1, seasonal H3N2, and highly pathogenic H5N1 influenza virus. Viral Immunol. 2011;24:179-87.

102. Guillot L, Le Goffic R, Bloch S, Escriou N, Akira S, Chignard M, Si-Tahar M. Involvement of toll-like receptor 3 in the immune response of lung epithelial cells to double-stranded RNA and influenza A virus. J Biol Chem. 2005;280:5571-80

103. Le Goffic R, Balloy V, Lagranderie M, Alexopoulou L, Escriou N, Flavell R, Chignard M, Si-Tahar M. Detrimental contribution of the Toll-like receptor (TLR)3 to influenza A virus-induced acute pneumonia. PLoS Pathog. 2006;2:e53.

104. Kawai T, Akira S. TLR signaling. Cell Death Differ. 2006;13:816-25.

105. Creagh EM, O'Neill LA. TLRs, NLRs and RLRs: a trinity of pathogen sensors that co-operate in innate immunity. Trends Immunol. 2006;27:352-7.

106. Marchant D, Singhera GK, Utokaparch S, Hackett TL, Boyd JH, Luo Z, Si X, Dorscheid DR, McManus BM, Hegele RG. Toll-like receptor 4-mediated activation of p38 mitogen-activated protein kinase is a determinant of respiratory virus entry and tropism. J Virol. 2010;84:11359-73.

107. Shirey KA, Lai W, Scott AJ, Lipsky M, Mistry P, Pletneva LM, Karp CL, McAlees J, Gioannini TL, Weiss J, et al. The TLR4 antagonist Eritoran protects mice from lethal influenza infection. Nature. 2013;497:498-502.

108. Sellge G, Kufer TA. PRR-signaling pathways: Learning from microbial tactics. Semin Immunol. 2015;27:75-84

109. Ware HH, Kulkarni W, Wang Y, Pantaleon Garcia J, Leiva Juarez M, Kirkpatrick CT, Wali S, Syed S, Kontoyiannis AD, Sikkema WKA, et al. Inducible lung epithelial resistance requires multisource reactive oxygen species generation to protect against bacterial infections. PloS One. 2019;14: e0208216.

110. Yeo SJ, Kim SJ, Kim JH, Lee HJ, Kook YH. Influenza A virus infection modulates the expression of type IV collagenase in epithelial cells. Arch Virol. 1999:144:1361-70.

111. Wang S, Quang Le T, Chida J, Cisse Y, Yano M, Kido H. Mechanisms of matrix metalloproteinase-9 upregulation and tissue destruction in various organs in influenza A virus infection. J Med Investig. 2010;57:26-34.

112. Lee $\mathrm{YH}$, Lai CL, Hsieh SH, Shieh CC, Huang LM, Wu-Hsieh BA. Influenza A virus induction of oxidative stress and MMP-9 is associated with severe lung pathology in a mouse model. Virus Res. 2013:178:411-22.

113. Bradley LM, Douglass MF, Chatterjee D, Akira S, Baaten BJ. Matrix metalloprotease 9 mediates neutrophil migration into the airways in response to influenza virus-induced toll-like receptor signaling. PLoS Pathog. 2012;8:e1002641.

114. Tang FS, Van Ly D, Spann K, Reading PC, Burgess JK, Hartl D, Baines KJ, Oliver BG. Differential neutrophil activation in viral infections: Enhanced TLR-7/8-mediated CXCL8 release in asthma. Respirology. 2016;21:172-9.

115. Uchide N, Obatake K, Yamada R, Sadanari H, Matsubara K, Murayama T, Ohyama K. Regulation of Matrix Metalloproteinases-2 and -9 Gene Expression in Cultured Human Fetal Membrane Cells by Influenza Virus Infection. Biol Pharm Bull. 1912-1921;2016:39

116. Kanneganti TD. Central roles of NLRs and inflammasomes in viral infection. Nat Rev Immunol. 2010;10:688-98.

117. Lamkanfi M, Kanneganti TD, Franchi L, Nunez G. Caspase-1 inflammasomes in infection and inflammation. J Leukoc Biol. 2007;82:220-5.
118. Sarvestani ST, McAuley JL. The role of the NLRP3 inflammasome in regulation of antiviral responses to influenza A virus infection. Antiviral Res. 2017;148:32-42.

119. Wang L, Negro R, Wu H. TRPM2, linking oxidative stress and $\mathrm{Ca}(2+)$ permeation to NLRP3 inflammasome activation. Curr Opin Immunol. 2020; 62:131-5.

120. Ichinohe T, Yamazaki T, Koshiba T, Yanagi Y. Mitochondrial protein mitofusin 2 is required for NLRP3 inflammasome activation after RNA virus infection. Proc Natl Acad Sci U S A. 2013;110:17963-8.

121. Yoshizumi T, Ichinohe T, Sasaki O, Otera H, Kawabata S, Mihara K, Koshiba T. Influenza A virus protein PB1-F2 translocates into mitochondria via Tom40 channels and impairs innate immunity. Nat Commun. 2014;5:4713.

122. Park, H.S.; Liu, G.; Thulasi Raman, S.N.; Landreth, S.L.; Liu, Q.; Zhou, Y. NS1 Protein of 2009 Pandemic Influenza A Virus Inhibits Porcine NLRP3 Inflammasome-Mediated Interleukin-1 Beta Production by Suppressing ASC Ubiquitination. J Virol 2018, 92

123. Park HS, Liu G, Liu Q, Zhou Y. Swine Influenza Virus Induces RIPK1/DRP1Mediated Interleukin-1 Beta Production. Viruses. 2018;10:419.

124. Erlich JR, To EE, Liong S, Brooks R, Vlahos R, O'Leary JJ, Brooks DA, Selemidis S. Targeting Evolutionary Conserved Oxidative Stress and Immunometabolic Pathways for the Treatment of Respiratory Infectious Diseases. Antioxid Redox Signal. 2020;32:993-1013.

125. Liu H, You L, Wu J, Zhao M, Guo R, Zhang H, Su R, Mao Q, Deng D, Hao Y. Berberine suppresses influenza virus-triggered NLRP3 inflammasome activation in macrophages by inducing mitophagy and decreasing mitochondrial ROS. J Leukoc Biol. 2020. https://doi.org/10.1002/JLB. 3MA0320-358RR.

126. Liu Q, Zhou YH, Yang ZQ. The cytokine storm of severe influenza and development of immunomodulatory therapy. Cell Mol Immunol. 2016; 13:3-10.

127. Huipao N, Borwornpinyo S, Wiboon-Ut S, Campbell CR, Lee IH, Hiranyachattada S, Sukasem C, Thitithanyanont A, Pholpramool C, Cook DI et al. P2Y6 receptors are involved in mediating the effect of inactivated avian influenza virus H5N1 on IL-6 \& CXCL8 mRNA expression in respiratory epithelium. PloS One. 2017;12:e0176974

128. Lamichhane PP, Samarasinghe AE. The Role of Innate Leukocytes during Influenza Virus Infection. J Immunol Res. 2019;2019:8028725.

129. Jung Kl, Ko DH, Shin N, Pyo CW, Choi SY. Endoplasmic reticulum-associated degradation potentiates the infectivity of influenza $A$ virus by regulating the host redox state. Free Radic Biol Med. 2019;135:293-305.

130. Roberson EC, Tully JE, Guala AS, Reiss JN, Godburn KE, Pociask DA, Alcorn JF, Riches DW, Dienz O, Janssen-Heininger YM, et al. Influenza induces endoplasmic reticulum stress, caspase-12-dependent apoptosis, and c-Jun $\mathrm{N}$-terminal kinase-mediated transforming growth factor-beta release in lung epithelial cells. Am J Respir Cell Mol Biol. 2012;46:573-81.

131. Pociask DA, Robinson KM, Chen K, McHugh KJ, Clay ME, Huang GT, Benos

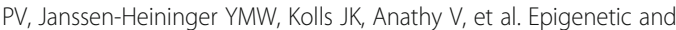
Transcriptomic Regulation of Lung Repair during Recovery from Influenza Infection. Am J Pathol. 2017:187:851-63.

132. Chamberlain N, Korwin-Mihavics BR, Nakada EM, Bruno SR, Heppner DE, Chapman DG, Hoffman SM, van der Vliet A, Suratt BT, Dienz O, et al. Lung epithelial protein disulfide isomerase A3 (PDIA3) plays an important role in influenza infection, inflammation, and airway mechanics. Redox Biol. 2019: 22:101129.

133. Mehrbod P, Ande SR, Alizadeh J, Rahimizadeh S, Shariati A, Malek H, Hashemi M, Glover KKM, Sher AA, Coombs KM, et al. The roles of apoptosis, autophagy and unfolded protein response in arbovirus, influenza virus, and HIV infections. Virulence. 2019;10:376-413.

134. Mileva M, Bakalova R, Tancheva L, Galabov A, Ribarov S. Effect of vitamin E supplementation on lipid peroxidation in blood and lung of influenza virus infected mice. Comp Immunol Microbiol Infect Dis. 2002;25:1-11.

135. Jacoby DB, Choi AM. Influenza virus induces expression of antioxidant genes in human epithelial cells. Free Radic Biol Med. 1994;16:821-4

136. Shibutani S, Takeshita M, Grollman AP. Insertion of specific bases during DNA synthesis past the oxidation-damaged base 8-oxodG. Nature. 1991;349: 431-4.

137. Pyo CW, Shin N, Jung Kl, Choi JH, Choi SY. Alteration of copper-zinc superoxide dismutase 1 expression by influenza A virus is correlated with virus replication. Biochem Biophys Res Commun. 2014;450:711-6.

138. Yatmaz S, Seow HJ, Gualano RC, Wong ZX, Stambas J, Selemidis S, Crack PJ, Bozinovski S, Anderson GP, Vlahos R. Glutathione peroxidase-1 reduces 
influenza A virus-induced lung inflammation. Am J Respir Cell Mol Biol. 2013:48:17-26.

139. Kosmider B, Messier EM, Janssen WJ, Nahreini P, Wang J, Hartshorn KL, Mason RJ. Nrf2 protects human alveolar epithelial cells against injury induced by influenza A virus. Respir Res. 2012;13:43.

140. Yamada Y, Limmon GV, Zheng D, Li N, Li L, Yin L, Chow VT, Chen J, Engelward BP. Major shifts in the spatio-temporal distribution of lung antioxidant enzymes during influenza pneumonia. PloS One. 2012;7:e31494.

141. Yageta Y, Ishii Y, Morishima Y, Masuko H, Ano S, Yamadori T, Itoh K, Takeuchi K, Yamamoto M, Hizawa N. Role of Nrf2 in host defense against influenza virus in cigarette smoke-exposed mice. J Virol. 2011;85: 4679-90.

142. Ludwig S, Planz O, Pleschka S, Wolff T. Influenza-virus-induced signaling cascades: targets for antiviral therapy? Trends Mol Med. 2003;9:46-52.

143. Simon PF, McCorrister S, Hu P, Chong P, Silaghi A, Westmacott G, Coombs KM, Kobasa D. Highly Pathogenic H5N1 and Novel H7N9 Influenza A Viruses Induce More Profound Proteomic Host Responses than Seasonal and Pandemic H1N1 Strains. J Proteome Res. 2015;14:4511-23.

144. Lin LT, Richardson CD. The Host Cell Receptors for Measles Virus and Their Interaction with the Viral Hemagglutinin (H) Protein. Viruses. 2016;8:250.

145. Huang Y, Zaas AK, Rao A, Dobigeon N, Woolf PJ, Veldman T, Oien NC, McClain MT, Varkey JB, Nicholson B, et al. Temporal dynamics of host molecular responses differentiate symptomatic and asymptomatic influenza a infection. PLoS Genet. 2011;7:e1002234.

146. Erkekoglu P, Asci A, Ceyhan M, Kizilgun M, Schweizer U, Atas C, Kara A, Kocer Giray B. Selenium levels, selenoenzyme activities and oxidant/ antioxidant parameters in H1N1-infected children. Turk J Pediatr. 2013;55: 271-82.

147. Soliman H, Mediavilla-Varela M, Antonia S. Indoleamine 2,3-dioxygenase: is it an immune suppressor? Cancer J (Sudbury, Mass.). 2010;16:354-9.

148. Choi AM, Knobil K, Otterbein SL, Eastman DA, Jacoby DB. Oxidant stress responses in influenza virus pneumonia: gene expression and transcription factor activation. Am J Physiol. 1996;271:L383-91.

149. Biswas M, Chan JY. Role of Nrf1 in antioxidant response element-mediated gene expression and beyond. Toxicol Appl Pharmacol. 2010;244:16-20.

150. Nencioni L, De Chiara G, Sgarbanti R, Amatore D, Aquilano K, Marcocci ME, Serafino A, Torcia M, Cozzolino F, Ciriolo MR, et al. BCl-2 expression and p38MAPK activity in cells infected with influenza A virus: impact on virally induced apoptosis and viral replication. J Biol Chem. 2009;284: 16004-15.

151. Meineke R, Rimmelzwaan GF, Elbahesh H. Influenza Virus Infections and Cellular Kinases. Viruses. 2019;11:171.

152. Hiscott J, Kwon H, Genin P. Hostile takeovers: viral appropriation of the NFkappaB pathway. J Med Investig. 2001;107:143-51.

153. Liu GH, Qu J, Shen X. NF-kappaB/p65 antagonizes Nrf2-ARE pathway by depriving CBP from Nrf2 and facilitating recruitment of HDAC3 to MafK. Biochimica et biophysica acta. 1783;2008:713-27.

154. Bergmann S, Elbahesh $\mathrm{H}$. Targeting the proviral host kinase, FAK, limits influenza a virus pathogenesis and NFkB-regulated pro-inflammatory responses. Virology. 2019;534:54-63.

155. Ohtsuka J, Matsumoto Y, Ohta K, Fukumura M, Tsurudome M, Nosaka T, Nishio M. Nucleocytoplasmic shuttling of the human parainfluenza virus type 2 phosphoprotein. Virology. 2019;528:54-63.

156. Marcos-Villar L, Diaz-Colunga J, Sandoval J, Zamarreno N, Landeras-Bueno S, Esteller M, Falcon A, Nieto A. Epigenetic control of influenza virus: role of H3K79 methylation in interferon-induced antiviral response. Sci Rep. 2018;8: 1230.

157. Torres M, Forman HJ. Redox signaling and the MAP kinase pathways. BioFactors. 2003;17:287-96.

158. Leslie NR. The redox regulation of PI 3-kinase-dependent signaling. Antioxid Redox Signal. 2006;8:1765-74

159. McCubrey JA, Lahair MM, Franklin RA. Reactive oxygen species-induced activation of the MAP kinase signaling pathways. Antioxid Redox Signal. 2006:8:1775-89.

160. Shin YK, Liu Q, Tikoo SK, Babiuk LA, Zhou Y. Effect of the phosphatidylinositol 3-kinase/Akt pathway on influenza A virus propagation. J Gen Virol. 2007;88:942-50.

161. Li Y, Lin Z, Guo M, Zhao M, Xia Y, Wang C, Xu T, Zhu B. Inhibition of H1N1 influenza virus-induced apoptosis by functionalized selenium nanoparticles with amantadine through ROS-mediated AKT signaling pathways. Int J Nanomed. 2018;13:2005-16.
162. Ehrhardt C, Marjuki H, Wolff T, Nurnberg B, Planz O, Pleschka S, Ludwig S. Bivalent role of the phosphatidylinositol-3-kinase (PI3K) during influenza virus infection and host cell defence. Cell Microbiol. 2006;8: 1336-48.

163. Yamada T, Horimoto H, Kameyama T, Hayakawa S, Yamato H, Dazai M, Takada A, Kida H, Bott D, Zhou AC, et al. Constitutive aryl hydrocarbon receptor signaling constrains type I interferon-mediated antiviral innate defense. Nat Immunol. 2016;17:687-94.

164. Gaelings L, Soderholm S, Bugai A, Fu Y, Nandania J, Schepens B, Lorey MB, Tynell J, Vande Ginste L, Le Goffic R, et al. Regulation of kynurenine biosynthesis during influenza virus infection. FEBS J. 2017;284:222-36.

165. Boule $L A$, Burke $C G$, Jin $G B$, Lawrence BP. Aryl hydrocarbon receptor signaling modulates antiviral immune responses: ligand metabolism rather than chemical source is the stronger predictor of outcome. Sci Rep. 2018;8: 1826

166. Meyers JL, Winans B, Kelsaw E, Murthy A, Gerber S, Lawrence BP. Environmental cues received during development shape dendritic cell responses later in life. PloS One. 2018;13:e0207007.

167. Franchini AM, Myers JR, Jin GB, Shepherd DM, Lawrence BP. Genome-Wide Transcriptional Analysis Reveals Novel AhR Targets That Regulate Dendritic Cell Function during Influenza A Virus Infection. ImmunoHorizons. 2019;3: 219-35.

168. Miyamoto S, Ronsein GE, Prado FM, Uemi M, Correa TC, Toma IN, Bertolucci A, Oliveira MC, Motta FD, Medeiros MH, et al. Biological hydroperoxides and singlet molecular oxygen generation. IUBMB Life. 2007;59:322-31.

169. Stanley CP, Maghzal GJ, Ayer A, Talib J, Giltrap AM, Shengule S, Wolhuter K, Wang $Y$, Chadha P, Suarna $C$, et al. Singlet molecular oxygen regulates vascular tone and blood pressure in inflammation. Nature. 2019;566:548-52.

170. Guillin OM, Vindry C, OhImann T, Chavatte L. Selenium. Selenoproteins Viral Infect Nutr. 2019:11:2101.

171. Fraternale A, Paoletti MF, Casabianca A, Oiry J, Clayette P, Vogel JU, Cinatl J Jr, Palamara AT, Sgarbanti R, Garaci E, et al. Antiviral and immunomodulatory properties of new pro-glutathione (GSH) molecules. Curr Med Chem. 2006;13:1749-55.

172. Hazafa A, Rehman KU, Jahan N, Jabeen Z. The Role of Polyphenol (Flavonoids) Compounds in the Treatment of Cancer Cells. Nutr Cancer. 2019:1-12. https://doi.org/10.1080/01635581.2019.1637006.

173. Garozzo A, Tempera G, Ungheri D, Timpanaro R, Castro A. N-acetylcysteine synergizes with oseltamivir in protecting mice from lethal influenza infection. Int J Immunopathol Pharmacol. 2007:20:349-54.

174. Geiler J, Michaelis M, Naczk P, Leutz A, Langer K, Doerr HW, Cinatl J Jr. Nacetyl-L-cysteine (NAC) inhibits virus replication and expression of proinflammatory molecules in A549 cells infected with highly pathogenic H5N1 influenza A virus. Biochem Pharmacol. 2010;79:413-20.

175. Ghezzi P, Ungheri D. Synergistic combination of N-acetylcysteine and ribavirin to protect from lethal influenza viral infection in a mouse model. Int J Immunopathol Pharmacol. 2004;17:99-102.

176. Zhang RH, Li CH, Wang CL, Xu MJ, Xu T, Wei D, Liu BJ, Wang GH, Tian SF. Nacetyl-I-cystine (NAC) protects against H9N2 swine influenza virus-induced acute lung injury. Int Immunopharmacol. 2014;22:1-8.

177. Garigliany MM, Desmecht DJ. N-acetylcysteine lacks universal inhibitory activity against influenza A viruses. J Negat Results Biomed. 2011;10:5.

178. Nencioni L, luvara A, Aquilano K, Ciriolo MR, Cozzolino F, Rotilio G, Garaci E, Palamara AT. Influenza A virus replication is dependent on an antioxidant pathway that involves GSH and BCl-2. FASEB J. 2003;17:758-60.

179. Braakman I, Helenius J, Helenius A. Role of ATP and disulphide bonds during protein folding in the endoplasmic reticulum. Nature. 1992;356: 260-2.

180. Sgarbanti R, Nencioni L, Amatore D, Coluccio P, Fraternale A, Sale P, Mammola CL, Carpino G, Gaudio E, Magnani M, et al. Redox regulation of the influenza hemagglutinin maturation process: a new cell-mediated strategy for anti-influenza therapy. Antioxid Redox Signal. 2011;15:593-606.

181. Limongi D, Baldelli S, Checconi P, Marcocci ME, De Chiara G, Fraternale A, Magnani M, Ciriolo MR, Palamara AT. GSH-C4 Acts as Anti-inflammatory Drug in Different Models of Canonical and Cell Autonomous Inflammation Through NFkappaB Inhibition. Front Immunol. 2019:10:155.

182. Amatore D, Celestino I, Brundu S, Galluzzi L, Coluccio P, Checconi P, Magnani M, Palamara AT, Fraternale A, Nencioni L. Glutathione increase by the n-butanoyl glutathione derivative (GSH-C4) inhibits viral replication and induces a predominant Th1 immune profile in old mice infected with influenza virus. FASEB bioAdvances. 2019;1:296-305. 
183. Friel $H$, Lederman $H$. A nutritional supplement formula for influenza $A$ (H5N1) infection in humans. Med Hypotheses. 2006;67:578-87.

184. Bhandary YP, Shetty SK, Marudamuthu AS, Midde KK, Ji HL, Shams H, Subramaniam R, Fu J, Idell S, Shetty S. Plasminogen activator inhibitor-1 in cigarette smoke exposure and influenza A virus infection-induced lung injury. Plos One. 2015;10:e0123187.

185. Forman HJ, Davies KJ, Ursini F. How do nutritional antioxidants really work: nucleophilic tone and para-hormesis versus free radical scavenging in vivo. Free Radic Biol Med. 2014;66:24-35.

186. Michaelis M, Sithisarn P, Cinatl J Jr. Effects of flavonoid-induced oxidative stress on anti-H5N1 influenza a virus activity exerted by baicalein and biochanin A. BMC Res Notes. 2014;7:384.

187. Ling JX, Wei F, Li N, Li JL, Chen L, Liu YY, Luo F, Xiong HR, Hou W, Yang $Z Q$. Amelioration of influenza virus-induced reactive oxygen species formation by epigallocatechin gallate derived from green tea. Acta Pharmacol Sin. 2012;33:1533-41.

188. Song JM, Lee KH, Seong BL. Antiviral effect of catechins in green tea on influenza virus. Antiviral Res. 2005;68:66-74.

189. Wu W, Li R, Li X, He J, Jiang S, Liu S, Yang J. Quercetin as an Antiviral Agent Inhibits Influenza A Virus (IAV) Entry. Viruses. 2015;8:6.

190. Awogbindin IO, Olaleye DO, Farombi EO. Mechanistic perspective of the oxido-immunopathologic resolution property of kolaviron in mice influenza pneumonitis. APMIS. 2017;125:184-96.

191. Jiang H, Shen SM, Yin J, Zhang PP, Shi Y. Sphingosine 1-phosphate receptor 1 (S1PR1) agonist CYM5442 inhibits expression of intracellular adhesion molecule 1 (ICAM1) in endothelial cells infected with influenza A viruses. PloS One. 2017;12:e0175188.

192. Lee JY, Abundo MEC, Lee CW. Herbal Medicines with Antiviral Activity Against the Influenza Virus, a Systematic Review. Am J Chin Med. 2018;46:1663-700.

193. Planz O. Development of cellular signaling pathway inhibitors as new antivirals against influenza. Antiviral Res. 2013;98:457-68.

194. Wang L, Jiang H, Shen SM, Wen CX, Xing Z, Shi Y. Inhibition of autophagy and chemokine induction by sphingosine 1-phosphate receptor 1 through NF-kappaB signaling in human pulmonary endothelial cells infected with influenza A viruses. PloS One. 2018;13:e0205344.

195. McCarty MF, Barroso-Aranda J, Contreras F. Practical strategies for targeting NF-kappaB and NADPH oxidase may improve survival during lethal influenza epidemics. Med Hypotheses. 2010;74:18-20.

196. van den Berg R, Haenen GR, van den Berg H, Bast A. Transcription factor NF-kappaB as a potential biomarker for oxidative stress. Br J Nutr. 2001; 86(Suppl 1):S121-7.

197. Wu H, Song W, Gao X, Liu N, Wang P, Chen H, Cai Z. Proteomics study of Nacetylcysteine response in $\mathrm{H} 1 \mathrm{~N} 1$-infected cells by using mass spectrometry. Rapid Commun Mass Spectrom. 2014;28:741-9.

198. Nencioni L, Sgarbanti R, De Chiara G, Garaci E, Palamara AT. Influenza virus and redox mediated cell signaling: a complex network of virus/host interaction. New Microbiol. 2007;30:367-75.

199. Uchide N, Ohyama K, Bessho T, Yuan B, Yamakawa T. Effect of antioxidants on apoptosis induced by influenza virus infection: inhibition of viral gene replication and transcription with pyrrolidine dithiocarbamate. Antiviral Res. 2002;56:207-17.

200. Qi X, Zhang H, Wang Q, Wang J. The NS1 protein of avian influenza virus H9N2 induces oxidative-stress-mediated chicken oviduct epithelial cells apoptosis. J Gen Virol. 2016;97:3183-92.

201. Uchide N, Ohyama K, Bessho T, Toyoda H. Inhibition of influenza-virusinduced apoptosis in chorion cells of human fetal membranes by nordihydroguaiaretic Acid. Intervirology. 2005;48:336-40.

202. Miyamoto D, Kusagaya Y, Endo N, Sometani A, Takeo S, Suzuki T, Arima Y, Nakajima K, Suzuki Y. Thujaplicin-copper chelates inhibit replication of human influenza viruses. Antiviral Res. 1998;39:89-100.

203. Uchide N, Toyoda H. Antioxidant therapy as a potential approach to severe influenza-associated complications. Molecules. 2011;16:2032-52.

204. Palamara AT, Nencioni L, Aquilano K, De Chiara G, Hernandez L, Cozzolino F, Ciriolo MR, Garaci E. Inhibition of influenza A virus replication by resveratrol. J Infect Dis. 2005;191:1719-29.

205. Huang YL, Loke SH, Hsu CC, Chiou WF. (+)-Vitisin A inhibits influenza A virusinduced RANTES production in A549 alveolar epithelial cells through interference with Akt and STAT1 phosphorylation. Planta Med. 2008;74:156-62.

206. Yang B, Yao DF, Ohuchi M, Ide M, Yano M, Okumura Y, Kido H. Ambroxol suppresses influenza-virus proliferation in the mouse airway by increasing antiviral factor levels. Eur Respir J. 2002;19:952-8.
207. Wang H, Xu R, Shi Y, Si L, Jiao P, Fan Z, Han X, Wu X, Zhou X, Yu F, et al. Design, synthesis and biological evaluation of novel $L$-ascorbic acidconjugated pentacyclic triterpene derivatives as potential influenza virus entry inhibitors. Eur J Med Chem. 2016;110:376-88.

208. Kim Y, Kim H, Bae S, Choi J, Lim SY, Lee N, Kong JM, Hwang Yl, Kang JS, Lee WJ. Vitamin C Is an Essential Factor on the Anti-viral Immune Responses through the Production of Interferon-alpha/beta at the Initial Stage of Influenza A Virus (H3N2) Infection. Immune Netw. 2013;13:70-4.

209. Cai Y, Li YF, Tang LP, Tsoi B, Chen M, Chen H, Chen XM, Tan RR, Kurihara H, He RR. A new mechanism of vitamin C effects on A/FM/1/47(H1N1) virusinduced pneumonia in restraint-stressed mice. BioMed Res Int. 2015;2015: 675149.

210. Kim H, Jang M, Kim Y, Choi J, Jeon J, Kim J, Hwang YI, Kang JS, Lee WJ. Red ginseng and vitamin $C$ increase immune cell activity and decrease lung inflammation induced by influenza A virus/H1N1 infection. J Pharm Pharmacol. 2016;68:406-20.

211. Antanasijevic A, Cheng H, Wardrop DJ, Rong L, Caffrey M. Inhibition of influenza H7 hemagglutinin-mediated entry. PloS One. 2013;8:e76363.

212. Antanasijevic A, Hafeman NJ, Tundup S, Kingsley C, Mishra RK, Rong L, Manicassamy B, Wardrop D, Caffrey M. Stabilization and Improvement of a Promising Influenza Antiviral: Making a PAIN PAINless. ACS Infect Dis. 2016;2: 608-15.

213. Richart SM, Li YL, Mizushina Y, Chang YY, Chung TY, Chen GH, Tzen JT, Shia KS, Hsu WL. Synergic effect of curcumin and its structural analogue (Monoacetylcurcumin) on anti-influenza virus infection. J Food Dug Anal. 2018;26:1015-23.

214. Sharma RA, McLelland HR, Hill KA, Ireson CR, Euden SA, Manson MM, Pirmohamed M, Marnett LJ, Gescher AJ, Steward WP. Pharmacodynamic and pharmacokinetic study of oral Curcuma extract in patients with colorectal cancer. Clin Cancer Res. 2001;7:1894-900.

215. Barzegar A, Moosavi-Movahedi AA. Intracellular ROS protection efficiency and free radical-scavenging activity of curcumin. PloS One. 2011;6:e26012.

216. Dai J, Gu L, Su Y, Wang Q, Zhao Y, Chen X, Deng H, Li W, Wang G, Li K. Inhibition of curcumin on influenza A virus infection and influenzal pneumonia via oxidative stress, TLR2/4, p38/JNK MAPK and NF-kappaB pathways. Int Immunopharmacol. 2018;54:177-87.

217. Dai JP, Wang QW, Su Y, Gu LM, Zhao Y, Chen XX, Chen C, Li WZ, Wang GF, Li KS. Emodin Inhibition of Influenza A Virus Replication and Influenza Viral Pneumonia via the Nrf2, TLR4, p38/JNK and NF-kappaB Pathways. Molecules. 2017:22

218. Zhou B, Yang Z, Feng Q, Liang X, Li J, Zanin M, Jiang Z, Zhong N. Aurantiamide acetate from baphicacanthus cusia root exhibits antiinflammatory and anti-viral effects via inhibition of the NF-kappaB signaling pathway in Influenza A virus-infected cells. J Ethnopharmacol. 2017;199:60-7.

219. Kim DH, Park GS, Nile AS, Kwon YD, Enkhtaivan G, Nile SH. Utilization of Dianthus superbus $L$ and its bioactive compounds for antioxidant, antiinfluenza and toxicological effects. Food Chem Toxicol. 2019;125:313-21.

220. Formica JV, Regelson W. Review of the biology of Quercetin and related bioflavonoids. Food Chem Toxicol. 1995;33:1061-80.

221. Nile SH, Kim DH, Nile A, Park GS, Gansukh E, Kai G. Probing the effect of quercetin 3-glucoside from Dianthus superbus $L$ against influenza virus infection- In vitro and in silico biochemical and toxicological screening. Food Chem Toxicol. 2020;135:110985

222. Zhao Y, Wang J, Ballevre O, Luo H, Zhang W. Antihypertensive effects and mechanisms of chlorogenic acids. Hypertens Res. 2012;35:370-4.

223. Shen W, Qi R, Zhang J, Wang Z, Wang H, Hu C, Zhao Y, Bie M, Wang Y, Fu $Y$, et al. Chlorogenic acid inhibits LPS-induced microglial activation and improves survival of dopaminergic neurons. Brain Res Bull. 2012;88:487-94.

224. Ding Y, Cao Z, Cao L, Ding G, Wang Z, Xiao W. Antiviral activity of chlorogenic acid against influenza $A(\mathrm{H} 1 \mathrm{~N} 1 / \mathrm{H} 3 \mathrm{~N} 2)$ virus and its inhibition of neuraminidase. Sci Rep. 2017;7:45723.

225. Kim HO, Yeom M, Kim J, Kukreja A, Na W, Choi J, Kang A, Yun D, Lim JW, Song D, et al. Reactive Oxygen Species-Regulating Polymersome as an Antiviral Agent against Influenza Virus. Small. 2017;13:1700818.

226. To EE, Luong R, Diao J, O'Leary JJ, Brooks DA, Vlahos R, Selemidis S. Novel endosomal NOX2 oxidase inhibitor ameliorates pandemic influenza A virusinduced lung inflammation in mice. Respirology. 2019:24:1011-7.

227. Qi X, Zhang H, Xue T, Yang B, Deng M, Wang J. Down-regulation of cellular protein heme oxygenase-1 inhibits proliferation of avian influenza virus H9N2 in chicken oviduct epithelial cells. J Gen Virol. 2018;99:36-43. 
228. Hossain MK, Saha SK, Abdal Dayem A, Kim JH, Kim K, Yang GM, Choi HY, Cho SG. Bax Inhibitor-1 Acts as an Anti-Influenza Factor by Inhibiting ROS Mediated Cell Death and Augmenting Heme-Oxygenase 1 Expression in Influenza Virus Infected Cells. Int J Mol Sci. 2018;19:712

229. Episcopio D, Aminov S, Benjamin S, Germain G, Datan E, Landazuri J, Lockshin RA, Zakeri Z. Atorvastatin restricts the ability of influenza virus to generate lipid droplets and severely suppresses the replication of the virus. FASEB J. 2019:33:9516-25.

230. Takahashi E, Indalao IL, Sawabuchi T, Mizuno K, Sakai S, Kimoto T, Kim H, Kido H. Clarithromycin suppresses induction of monocyte chemoattractant protein-1 and matrix metalloproteinase- 9 and improves pathological changes in the lungs and heart of mice infected with influenza A virus. Comp Immunol Microbiol Infect Dis. 2018;56:6-13.

231. Nagai T, Miyaichi Y, Tomimori T, Yamada H. Inhibition of mouse liver sialidase by plant flavonoids. Biochem Biophys Res Commun. 1989;163:25-31.

232. Nagai T, Miyaichi Y, Tomimori T, Suzuki Y, Yamada H. Inhibition of influenza virus sialidase and anti-influenza virus activity by plant flavonoids. Chem Pharm Bull. 1990;38:1329-32.

233. Nagai T, Miyaichi $Y$, Tomimori T, Suzuki Y, Yamada H. In vivo anti-influenza virus activity of plant flavonoids possessing inhibitory activity for influenza virus sialidase. Antiviral Res. 1992;19:207-17.

234. Nagai T, Suzuki Y, Tomimori T, Yamada H. Antiviral activity of plant flavonoid, 5,7,4'-trihydroxy-8-methoxyflavone, from the roots of Scutellaria baicalensis against influenza $A(\mathrm{H} 3 \mathrm{~N} 2)$ and B viruses. Biological \& pharmaceutical bulletin. 1995;18:295-9.

235. Nagai T, Moriguchi R, Suzuki Y, Tomimori T, Yamada H. Mode of action of the anti-influenza virus activity of plant flavonoid, 5,7,4'-trihydroxy-8-methoxyflavone, from the roots of Scutellaria baicalensis. Antiviral Res. 1995:26:11-25.

236. Kuzuhara T, Iwai Y, Takahashi H, Hatakeyama D, Echigo N. Green tea catechins inhibit the endonuclease activity of influenza A virus RNA polymerase. PLoS Curr. 2009;1:RRN1052.

237. Choi HJ, Song JH, Park KS, Kwon DH. Inhibitory effects of quercetin 3rhamnoside on influenza A virus replication. Eur J Pharm Sci. 2009;37:329-33.

238. Gangehei L, Ali M, Zhang W, Chen Z, Wakame K, Haidari M. Oligonol a low molecular weight polyphenol of lychee fruit extract inhibits proliferation of influenza virus by blocking reactive oxygen species-dependent ERK phosphorylation. Phytomedicine. 2010;17:1047-56.

239. Pica N, Palese $P$. Toward a universal influenza virus vaccine: prospects and challenges. Annu Rev Med. 2013;64:189-202.

240. Nabar GM, Mahajan KD, Calhoun MA, Duong AD, Souva MS, Xu J, Czeisler C, Puduvalli VK, Otero JJ, Wyslouzil BE, et al. Micelle-templated, poly(lactic-Coglycolic acid) nanoparticles for hydrophobic drug delivery. Int J Nanomed. 2018:13:351-66

241. Lin Z, Li Y, Gong G, Xia Y, Wang C, Chen Y, Hua L, Zhong J, Tang Y, Liu X, et al. Restriction of H1N1 influenza virus infection by selenium nanoparticles loaded with ribavirin via resisting caspase-3 apoptotic pathway. Int J Nanomed. 2018:13:5787-97.

242. Chida J, Hara H, Yano M, Uchiyama K, Das NR, Takahashi E, Miyata H, Tomioka $Y$, Ito $T$, Kido $H$, et al. Prion protein protects mice from lethal infection with influenza A viruses. PLoS Pathog. 2018;14:e1007049.

243. Kode SS, Pawar SD, Tare DS, Keng SS, Hurt AC, Mullick J. A novel I117T substitution in neuraminidase of highly pathogenic avian influenza H5N1 virus conferring reduced susceptibility to oseltamivir and zanamivir. Vet Microbiol. 2019;235:21-4

244. Tomozawa T, Hoshino K, Yamashita M, Kubo S. Efficacy of laninamivir octanoate in mice with advanced inflammation stage caused by infection of highly lethal influenza virus. J Infect chemother. 2019;25:584-8.

245. Scott LJ. Peramivir: A Review in Uncomplicated Influenza. Drugs. 2018;78: 1363-70.

246. Alves Galvao, M.G.; Rocha Crispino Santos, M.A.; Alves da Cunha, A.J. Amantadine and rimantadine for influenza $A$ in children and the elderly. Cochrane Database Syst Rev 2014, https://doi.org/10.1002/14651858. CD002745.pub4, CD002745.

247. Zhang J, Hu Y, Hau R, Musharrafieh R, Ma C, Zhou X, Chen Y, Wang J. Identification of NMS-873, an allosteric and specific p97 inhibitor, as a broad antiviral against both influenza A and B viruses. Eur J Pharm Sci. 2019;133:86-94.

248. O'Hanlon R, Shaw ML. Baloxavir marboxil: the new influenza drug on the market. Curr Opin Virol. 2019:35:14-8.

249. Liu T, Liu M, Chen F, Chen F, Tian Y, Huang Q, Liu S, Yang J. A SmallMolecule Compound Has Anti-influenza A Virus Activity by Acting as a "PB2 Inhibitor". Mol Pharm. 2018;15:4110-20.
250. Jang Y, Shin JS, Yoon YS, Go YY, Lee HW, Kwon OS, Park S, Park MS, Kim M. Salinomycin Inhibits Influenza Virus Infection by Disrupting Endosomal Acidification and Viral Matrix Protein 2 Function. J Virol. 2018;92:e01441-18.

251. Hu Y, Hau RK, Wang Y, Tuohy P, Zhang Y, Xu S, Ma C, Wang J. StructureProperty Relationship Studies of Influenza A Virus AM2-S31N Proton Channel Blockers. ACS Med Chem Lett. 2018;9:1111-6.

252. Goldhill DH, Te Velthuis AJW, Fletcher RA, Langat P, Zambon M, Lackenby A, Barclay WS. The mechanism of resistance to favipiravir in influenza. Proc Natl Acad Sci U S A. 2018:115:11613-8.

253. Lee ACY, To KKW, Zhang AJX, Zhu H, Li C, Zhang RR, Hung IFN, Kao RYT, Chan KH, Yuen KY. Triple combination of FDA-approved drugs including flufenamic acid, clarithromycin and zanamivir improves survival of severe influenza in mice. Arch Virol. 2018;163:2349-58.

254. Chen H, Humes ST, Robinson SE, Loeb JC, Sabaraya IV, Saleh NB, Khattri RB, Merritt ME, Martyniuk CJ, Lednicky JA, et al. Single-walled carbon nanotubes repress viral-induced defense pathways through oxidative stress. Nanotoxicology. 2019;13:1176-96.

255. Sanpui P, Zheng X, Loeb JC, Bisesi JH Jr, Khan IA, Afrooz AR, Liu K, Badireddy AR, Wiesner MR, Ferguson PL, et al. Single-walled carbon nanotubes increase pandemic influenza A H1N1 virus infectivity of lung epithelial cells. Part Fibre Toxicol. 2014;11:66

256. Heaton BE, Kennedy EM, Dumm RE, Harding AT, Sacco MT, Sachs D, Heaton NS. A CRISPR Activation Screen Identifies a Pan-avian Influenza Virus Inhibitory Host Factor. Cell Rep. 2017;20:1503-12

257. Saito S, Lin YC, Tsai MH, Lin CS, Murayama Y, Sato R, Yokoyama KK. Emerging roles of hypoxia-inducible factors and reactive oxygen species in cancer and pluripotent stem cells. Kaohsiung J Med Sci. 2015;31:279-86.

258. Saito S, Lin YC, Nakamura Y, Eckner R, Wuputra K, Kuo KK, Lin CS, Yokoyama KK. Potential application of cell reprogramming techniques for cancer research. Cell Mol Life Sci. 2019;76:45-65.

\section{Publisher's Note}

Springer Nature remains neutral with regard to jurisdictional claims in published maps and institutional affiliations.
Ready to submit your research? Choose BMC and benefit from:

- fast, convenient online submission

- thorough peer review by experienced researchers in your field

- rapid publication on acceptance

- support for research data, including large and complex data types

- gold Open Access which fosters wider collaboration and increased citations

- maximum visibility for your research: over $100 \mathrm{M}$ website views per year

At BMC, research is always in progress.

Learn more biomedcentral.com/submission 